University of Rhode Island

DigitalCommons@URI

Open Access Master's Theses

1984

\title{
A Critique of Kennedy's Policy Towards Peking
}

Christopher Paul Wilson

University of Rhode Island

Follow this and additional works at: https://digitalcommons.uri.edu/theses

\section{Recommended Citation}

Wilson, Christopher Paul, "A Critique of Kennedy's Policy Towards Peking" (1984). Open Access Master's Theses. Paper 1794.

https://digitalcommons.uri.edu/theses/1794

This Thesis is brought to you for free and open access by DigitalCommons@URI. It has been accepted for inclusion in Open Access Master's Theses by an authorized administrator of DigitalCommons@URI. For more information, please contact digitalcommons@etal.uri.edu. 
A CRITIQUE OF KENNEDY'S

POLICY TOWARDS

\section{PEKING}

BY

CHRISTOPHER PAUL WILSON

A THESIS SUBMITTED IN PARTIAL FULFILLMENT OF THE

REQUIREMENTS FOR THE DEGREE OF

MASTER OF ARTS

IN

HISTORY

UNIVERSITY OF RHODE ISLAND

1984 


\section{ABSTRACT}

The purpose of this study was to make a thorough investigation of the available sources on the kennedy administration's foreign relations with the People's Republic of China. In carrying out this inquiry, the primary emphasis has been on attempting to make sense of the fragments and pieces of information related to the administration. Despite the fact that over twenty years have passed, there remains a vacuum in regards to a definitive statement on Kennedy's attitude towards the Chinese Communists. This study attempts to put the policy in a. proper perspective.

A great deal of relevant material remains classified by the State Department and other governmental agencies. However, the John F. Kennedy Library in Dorchester, Massachusetts proved to be a valuable resource for existing decassified material. Overall, the personal papers of members of the administration and other relevant documents emerged as the most useful information in the investigation. In addition to the Kennedy Library, declassified documents, published by Carrollton Press were also utilized and added to the study greatly. Most secondary sources were either biographies on Kennedy or superficial critiques of his administration. These sources were found at the University of Rhode Island in Kingston and at the Rockefeller Library on the campus of Brown University located in Providence, Rhode Island. Due to the nature of the secondary sources, the primary documents proved to be the essential resources for the research. 
This investigation has led to certain conclusions. Kennedy's actions, in conjunction with the recommendations from members of his administration, led to a policy towards Peking that maintained the tense relations of the previous administration. There was a lack of preparation, understanding, and foresight on Keneedy's part. Instead of thinking of the future, he chose to ignore alternatives that could have bettered Sino-American relations. This was illustrated within several issues such as the Sino-Soviet split, the United Nations question, and the issue of disarmament. When Kennedy looked beyond the horizon in regards to the China policy, he failed to accept any alternatives that could create better relations. In relation to his policy on China, Kennedy was an indecisive leader. True, Kennedy was hindered by the China Lobby and by the United States' relationship with the Chinese Nationalists. However, Kennedy was too willing to use these as excuses.

It is important to keep in mind the clarity that hindsight brings to the scholar. Kennedy was dealing with an America that remembered China as an ally. However, Kennedy did nothing to change this and allowed a stagnant policy to continue. 


\section{ACKNOWLEDGEMENTS}

It is the wish of the author to express gratitude to all members of his thesis committee, especially Dr. Frank Costigliola, who was always willing to offer direction, guidance, and a thoughtful push. Also, a special thanks to Larry Severeid for his brilliant editing ability. Finally, deep appreciation to Nancy Paxton for her willingness to understand what a thesis is all about. 
Chapter

I. INTRODUCTION . . . . . . . . . . . . . . 1

Pre-Presidential Policy

The Administration

Kennedy's Apprehension

on the Eve

II. THE UNITED NATIONS QUESTION. . . . . . . . 16

Historical Basis

Initial Steps

Bracing For a storm

The Kennedy Legacy

III. THE SINO-SOVIET SPLIT. . . . . . . . . . . 27

The Administration and Communism

Initial Reactions

American Response

IV. THE POLICY OF CONTAINMENT. . . . . . . . . . 39

Willing to Act

Laos

Alternatives

Review of the Laos Policy

India

Reflections

V. THE FOOD CRISIS. . . . . . . . . . . 57

1962: The Pivotal. Year

Factions within

To Offer or Not to Offer

Implications

VI. DISARMAMENT AND CHINA. . . . . . . . . 67

Kennedy Hopes

The Test Ban and China

The Horizon

VII. CONCLUSIONS. . . . . . . . . . . . . . 74 SOURCE NOTES. . . . . . . . . . . . . . . . . . . . . 79 SELECTED BIBLIOGRAPHY . . . . . . . . . . . . . . 80 
CHAPTER I

INTRODUCTION

John Kennedy's overall foreign policy.slowly emerged after he was nominated by the Democratic Party in 1960 for the Presidency. His foreign policy gave him the image of being his own man in terms of foreign relations. More important to this study, Kennedy's presidential China policy began to emerge. In the end, this image of Kennedy being his own man was false because the new President actually embraced the China policy of his immediate predecessor.

\section{Pre-Presidential Policy}

As a member of the United States House of Representatives from 1946 through 1952, Kennedy had the opportunity to play a role in the china issue. When the kuomintang regime of Chiang Kai-shek fell in 1949, the young Congressman from Massachusetts had been a harsh critic of the Truman administration and its policies. In a speech in Salem, Massachusetts following the overthrow of Chiang, Kennedy stated that these policies caused the regime to collapse under pressure from the communist forces, commenting, "what our young men have saved, our diplomats and President have frittered away." 1 Although

${ }^{1}$ Foster Rhea Dulles, American Policy Toward Communist China (New York: Thomas Y. Crowell, 1972), p. 189. 
he later felt badly about this harsh statement, the speech itself was indicative of 'Kennedy's posture throughout most of the $1950 \cdot \mathrm{s}$ in relation to the China question. This posture would of course also influence his China policy as President. Kennedy was elected to the Senate in 1952, the same year as the overwhelming Eisenhower victory, which saw conservatism reemerging in the United States. As Senator, Kennedy rarely deviated from the Eisenhower policy towards the Chinese Communists, accepting the Republican theme of non-recognition. Included in this policy was the American support of the Chinese Nationalists who were exiled on the island of Taiwan under the leadership of Chiang.

Included in Kennedy's support for the Eisenhower policy was the Senator's vote for the 1955 "Formosa Resolution", a mutual defense agreement between the United States and the island of Taiwan. In short, the senate resolution endorsed the treaty, accepting the idea of using American troops to protect Taiwan and the offshore islands from possible aggression from the mainland. 2

The first crisis related to this treaty occured in.1958, the so-called "Taiwan Straits" conflict. Kennedy, deviating from his previous stance, criticized Eisenhower's plan for military operations. On September 18, Kennedy, shifting his policy somewhat more to the center, declaring that "the weight of

${ }^{2}$ China and U.S. Far East Policy, 1945-1967. (Washington, D.C.: Congressional Quarterly Service, 1967), p. 72. 
military, diplomatic, political, and historical judgement would dictate a contrary policy." ${ }^{3}$ Kennedy and his Democratic allies saw the Republican administration as too willing to use American military forces in the Taiwan region. Although Kennedy was not in favor of advocating a change in the U.S. policy, especially in regard to recognizing the Chinese communists, he was moving somewhat away from the Eisenhower policy. The Senator constantly spoke of the direct threat the Peking government posed to American interests in the Far East, yet he was also willing to cniticize the inflexibility of the Eisenhower administration. 4 In 1957, a year before his public criticism of Eisenhower, Kennedy had written an article titled "A Democrat Looks at Foreign Folicy:" In this journal piece the Senator was openly critical of the state of American-Sino relations. Kennedy explained that "in Asia our policy has been too rigid... we must be very careful not to straitjacket our policy as a result of ignorance and fail to detect a change in the situation when it comes." 5 It is obvious that kennedy's opinion on China was not black and white. The Senator was unwilling to completely break from the Eisenhower policy, but expressed his dislike for its inflexibility. He refused to ad-

3 Ibid., p. 17 .

4 Dulles, American Policy Toward Communist China, p. 189.

5 John F. Kennedy, "A Democrat Looks at Foreign Policy". Foreign Affairs 30 (October, 1957): 50 . 
vocate a new policy, but looked to alter the Eisenhower tactics. In the years to come, with his election into the white House, this policy, unfortunately, would continue. Kennedy may have been critical of some of Eisenhower's inflexible aspects in regard to China, but in 1960 Kennedy would continue the same policy.

The most obvious reason for this continuation was Kennedy's conservatism in foreign policy. In addition to this, the new President refused to accept the reality of the China situation. Kennedy, as President, was too cautious and too short-sighted to commit himself to a re-evaluation of the American policy, allowing the United States and the People's Republic of China to remain bitter enemies. Throughout Kennedy's administration, these shortcomings would lead to a dismal showing for the President and his administration in relation to the American China policy.

\section{The Administration}

Kennedy's victory in 1960 was no mandate from the American people. His margin of victory, less than one hundred fifty thousand votes, played a significant role in the extent to which the new President felt he could move towards a new, more flexible China policy.

Kennedy depended on various administrative and departmental personnel to formulate his administration's foreign policy. These selected members proposed, edited, and suggested policy ideas, providing Kennedy with opposing viewpoints from which to select. In order to understand the kennedy foreign 
policy, its evolution and justifications, it is necessary to see who, if anyone, was influencing the President on foreign policy, especially in relation to the administration's China policy.

Roger Hilsman, Assistant Secretary of State in the Kennedy administration, maintained in his biography on the Kennedy years that the new President believed in streamlining the foreign policy process in order to place most of the responsibility on the State Department. In relation to this, Hilsman continued, Kennedy eliminated the Operations Coordination Board and relegated the National Security Council to "special problems" status. 6 If Hilsman was correct in his assessment of Kennedy's administrative organization, then it is apparent that the Secretary of State would be apportioned an even larger amount of responsibility than normal. This meant the Secretary would have to be capable of creating and executing policy in addition to overseeing the added administrative details. Dean Rusk, a little-known individual in 1960, was selected by Kennedy to fill this prestigious post. At the time, Rusk was Director of the Rockefeller Foundation and had been out of government since 1953. In 1960, he was a difficult man to label as conservative or liberal; whether he supported the status quo or sought to alter American foreign policy. Foster Rhea Dulles, in his American Policy Toward Communist China,

${ }^{6}$ Roger Hilsman, To Move a Nation (Garden City, New york: Doubleday and Company, Inc., 1967), p. 23. 
1949-1969, mairtains that Rusk's appointment "strongly militated against any shift in our position in the Far East." 7 Thomas G. Paterson, an expert in diplomatic history, agrees with Dulles. Paterson believes Rusk, as well as others in the Kennedy administration, looked back to the 1940's and $1950^{\prime}$ 's for inspiration and guidance for developing foreign policy. This would classify Rusk as a Cold Warrior. ${ }^{8}$

Kennedy was of course interested in Rusk's philosophy on foreign relations, but it seems as though something else attracted the President-elect to the native Georgian. In 1960 Rusk had written an article entitled, "The President." In the article Rusk concluded that the Chief Executive should more or less be his own Secretary of State, formulating his own foreign policy. ${ }^{9}$ By advocating this policy in public, Rusk -inadvertantly promoted himself as Kennedy's Secretary appointment. Rusk's theory attracted Kennedy, who also held a similar philosophy.

other scholars who disagree with the above conclusions defend Rusk and maintain that he was not to blame for the lack of progress on the China policy. Warren Cohen, in his biography of the former Secretary of State, maitained that

${ }^{7}$ Dulles, American Policy Toward Communist China, p. 191.

8 Thomas G. Paterson, "Bearing the Burden: A Critical Look at JFK's Foreign Policy" The Virginia Quarterly Review 54 (Spring, 1978): 197.

9 Dean Rusk, "The President" Foreign Affairs 38 (April, 1960): 353-369. 
Kennedy himself was pushing for the militant Eisenhower policy, By moving to dominate his administration's policy, Kennedy, according to Cohen, tried to use Rusk merely as a figurehead. In addition to this, Cohen disagreed with both Dulles and Paterson on Rusk's foreign policy views, believing the Secretary was an open-minded individual when it came to relations with the Chinese Communists. Cohen stated that Rusk understood that Eisenhower's policy was wrong since the government of Peking was going to be around for a long time. In regard to this, Rusk believed that the Chinese Communists had to be involved in a variety of world affairs. ${ }^{10}$ If cohen's interpretation is correct, then Rusk was not the villain within the administration as his critics have charged. Rather it was Kennedy or other advisors who hedged on creating a new, more realistic policy towards Peking.

Cohen's argument, however, is not quite this simple. While his support for Rusk remains throughout his book, he also paints a darker picture of Rusk. In 1951 Rusk made a speech highly critical of the Peking regime while full of praise for the Nationalists. Cohen concluded that Rusk was not willing to return to a hard-line policy, but "he did seem to feel a deep hostility towards the Chinese Communists, stemming from the Korean war."11 Thus it becomes more difficult to assign blame for the administration's China policy.

10 Warren Cohen, Dean Rusk (Totowa, New Jersey: Cooper Square Publishers, 1980), p. 94, 163.

$11_{\text {Ibid., p. } 163 .}$ 
Another author's viewpoint appeairs as a more logical explanation of what actually occured in this relationship between the President and his Secretary of State. Roger Hilsman was a friend and associate to both men, providing a unique vantage point from which to evaluate their relationship. Hilsman maintained that their relationship soured over time. growing colder which hindered the working arrangement and atmosphere. Hilsman was convinced that kennedy wanted Rusk to be an active member of the administration. However, he concluded that Rusk's status with Kennedy dropped dramatically in April, 1961 when the Secretary failed to take the leadership role during the Bay of Pigs operation. 12 After this, Kennedy began to take the lead in formulating policy, distrusting his secretary of state. This does not mean Rusk was completely out of the policy process, rather Hilsman appeared to indicate that foreign. policy revolved around the White House and not the State Department. This indicates Kennedy was more to blame for the administration's China policy and its lack of flexibility than Rusk and the state Department.

Another member of the administration who played a significant role in the China policy was Adlai E. Stevenson, the American Ambassador to the United Nations. Stevenson had long professed to close friends his wish for the Secretary of state position, but Kennedy passed him over, hoping to avoid criticism from the conservative factions. Also, the two men had 
serious personal differences. In terms of the China issue, Stevenson historically was critical of the Eisenhower policy of non-recognition and wrote to kennedy on several occasions, suggesting a policy reevaluation. In November, 1960, a week after the Kennedy victory, the President-elect asked Stevenson for a series of policy recommendations on issues that would confront the new administration. In this long report, stevenson concluded that there was a need to reevaluate the existing China policy, moving away from non-recognition and towards à policy that would hopefully be a step towards better relations with the People's Republic. 13 stevenson was not content to stop there; he also wrote Kennedy's personal aide, Theodore Sorenson, offering suggestions on items to include within the Kennedy inaugural address. Stevenson advised Sorenson to include "perthapg: a conditioned hint of re-examination of our China policy to advance controlled disarmament and reduce the danger of war in Asia."14 Both Kennedy and Sorenson chose to ignore these recommendations, hoping to let the policy stand as it did. Always the company man, stevenson did not push for these recommendations. Perhaps he was not in the position to initiate policy re-examinations. His participation would increase on the China isse, but to what extent is debatable.

\section{Stevenson Report, November, 1960. Box 1074, Pre-} Presidential Papers of John F. Kennedy. John F. Kennedy Library Archives, Dorchester, Massachusetts.

${ }^{14}$ Waiter Johnson, ed., Papers of Adlai E. Stevenson, Volume VII, (Boston: Little, Brown, and Company, 1977), p. 605 . 
One other "liberal" in the administration, also with some degree of input on the China policy was Under Secretary of State Chester Bowles. Bowles, like Stevenson, was passed over for the Secretary of State position due to his foreign policy philosophy. Yet Kennedy knew Bowles was an asset to his administration since he strengthened Kennedy's position with liberal Democrats. Bowles, as did others in the administration, had written an article on foreign affairs in the year preceding the Kennedy tenure in the White House. This article dealt with the China issue and American policy. Advocating that the U.S. Should look to create a "two-Chinas" policy, Bowles called for American acceptance of the existence of the Chinese Communists. 15 with this type of philosophy, it is clear to see why Kennedy was apprehensive about Chester Bowles.

These three men would eventually have a great deal of say in the administration's policy towards the Chinese communists. of course, there would be others, such as Walter Rostow, McGeorge Bundy, and Roger Hilsman, who would contribute to the policy. Hoverer, in 1960 and 1961, these men, Kennedy, Rusk, Stevenson, and Bowles, were the focal point of the policy.

\section{Kennedy's Apprehension}

As the new administration prepared for its entry into office, Kennedy had time to take notice of what he believed to be opposition to a new, more flexible policy towards the People's Republic of China. The first movement of opposition was the

${ }^{15}$ Chester Bowles, "The China Policy Reconsidered" Foreign Affairs 38 (April, 1960): 340-352. 
China Lobby, specifically, the Committee of one Million. Organized in 1953, this pro-Nationalist group began with a petition that opposed the admission of the Chinese Communists to the United Nations. The organization's goal was to collect the signatures of one million Americans and so gave the group its name. After this goal was reached, the petition was presented to Congress and the Committee of one Miliion disbanded for several years. 16 When Kennedy was elected in 1960 the leaders of the Committee grew apprehensive, fearing that the young President-elect might initiate a new china policy. One reason for this anxiety was an Associated Press dispatch of December, 1960 quoting Kennedy as "needing twelve months to prepare the American people for the People's Republic of China's admission to the U.N."17 Although this report was never confirmed, it was taken by the Committee as a warning: Members of the group began to lobby Congress, others wrote Kennedy expressing their views, and the committee began to take out advertisements in selected newspapers to try and raise the conciousness of the American public. Forrest Davis and Robert $A$. Hunter, two members of the Committee, published a book during Kennedy's term in office. The book was mostly propaganda, including the theme of Kennedy in the midst

\section{${ }^{16}$ China and the U.S. Far East Policy, 1949-1967,} pp. $24-25$.

17 Stanley D. Bachrack, The Committee of one Million (New York: Columbia University Press, 1976), p. 184 
of an "agonizing reappraisal" of the administration's China policy. 18 The Committee of one Million was not the only member of the China Lobby, but as illustrated above, it certainly was one of the most organized and resourceful groups at the time.

Supporters of Kennedy's China policy concluded that the President's hands were tied by the China Lobby and by the conservative members of Congress, many of whom belonged to such groups as the Committee of one Million. In 1961 alone, there were fourteen resolutions in the U.S. House of Representatives that called for the continued support of the Chinese Nationalists and the non-recognition of the Chinese communists. ${ }^{19}$ If Kennedy was looking to a second term in office, he had to keep this issue in mind.

The Kennedy supporters who claimed his hands were tied may have overstated their case. Perhaps in 1961 Kennedy did face a formidable obstacle in the China Lobby and in Congress; however, both were merely that - an obstacle that had to be dealt with - something Kennedy chose not to do. James $C$. Thomson Jr., a member of the State Department in the 1960's, correctly points out that Kennedy's victory in 1960 was the return of the Democrats to the White House after eight years and, Thomson concluded, the reason for the eight year absence

${ }^{18}$ Forrest Davies and Robert A. Hunter, The Red China Lobby (New York: Fleet Publishing Corporation, 1963), p. 107. 19 Bachrack, The Committee of one Million, p. 201. 
was due to the previous Democratic administration's Far East policy. 20 In short, Thomson stated that Kennedy did not want to bring up a sore spot of the party so quickly, and this makes sense. However, this argument does not suffice for Kennedy's entire tenure.

Another area Kennedy felt apprehensive about was the public opinion about foreign policy. The President-elect believed he faced a movement that ran counter to any thoughts of creating a new China policy. Kennedy realized that he needed a supportive electorate if he wished to change policy. What Kennedy did not realize was that he did have the support of the American people. The public was not closed-minded on the subject of China and those supporters of Kennedy who maintained that the public was against recognizing Peking were blind to the facts. 21

\section{On the Eve}

In 1960 and 1961, Kennedy's China policy was muddled. The new President had no patience with the idea that Taiwan represented all of China, but feared the domestic political liabilities that could arise if he changed policy. ${ }^{22}$ He con-

${ }^{20}$ James C. Thomson Jr. "On the Making of U.S. China Policy, 1961-1969: A Study in Bureaucratic Politics" China Quarterly $50(1972): 220-221$.

$21_{A}$.T. Steele The American People and China (New York: Morsaw-Hill, 1966), p. 266 .

${ }^{22} \mathrm{John}$ Lewis Gaddis, Strategies of Containment (New York: oxford University Press, 1982), p. 230 . 
fided to close friends that any real changes in policy might have to wait until the second term. ${ }^{23}$ Publicly, Kennedy said the same thing. In a March, 1961 news conference he insisted, "I would like to see a lessening of tensions with the Chinese communists." 24

Despite these statements, on the eve of his administration, and for most of his tenure in office, Kennedy accepted and maintained the inherited policy. Basically, this included the non-recognition of the People's Republic, a firm opposition to the admission of Peking to the United Nations, the maintenance of defending Taiwan in the case of attack by the chinese Communists, and any and all assistance to nations near or bordering the China mainland. 25

The only significant area in which Kennedy differed from the Eisenhower administration was on the issue of the offshore islands, Quemoy and Matsu. During the 1960 campaign, Kennedy and opponent Richard Nixon generally agreed on the China issue, but differed on this specific topic. In the first presidential debate, Nixon stated that the two islands, both situated approximately five miles off the coast of mainland China, were symbolic in that the United states would defend them as a means

23 Thomson, "On the Making of U.S. China Policy, 1961-1969: A Study in Bureaucratic Politics" p. 222.

${ }^{24}$ Hilsman, To Move a Nation, p. 273.

25 China and the U.S., 1955-1963. ed.Kwan Ha Yim (New York: Facts on File, Inc., 1973), p. 137. 
of showing the Chinese Communists that the U.S. would not give up an inch of land without a fight. Kennedy rebutted the Vice-President, stating, "I think it's unwise to take a chance of being dragged into a war which may lead to world war over two islands which are not strategically defensible..."26 For Kennedy, this rebuttal was a dramatic move and he refused to take another on the China issue.

John F. Kennedy took office in 1961 with a group of men full of confidence, advocating action and a new..theme. Yet for most of these men this meant an adherance to the ideals of the Cold War. The New Frontier was nothing more than a change in tactics on dealing with communism. By maintaining the ideals of the Cold War, the administration hindered itself when it talked of a new China policy.

${ }^{26}$ Democratic National Committee Newsletter, October, 1960. Box 1030, Pre-Presidential Papers of John F. Kennedy. 
CHAPTER II

THE UNITED NATIONS QUESTION

\section{Historical Basis}

The first major issue facing the administration, in terms of its China policy, was the status of the Chinese representation in the United Nations. In addition to being the first issue on the China question, it was also the most feared by Kennedy. Political consequences, according to Kennedy, would be catastrophic if the U.S. changed its policy on this specific issue. Prior to 1961 , the policy had been to actively oppose the admission of the Chinese Communists. This included lobbying for an American resolution that opposed any change in the status of Chinese representation. The U.S. had backed the Nationalists as the rightful government for all Chinese since 1951, refusing to recognize the legitimacy of the Peking government. The American resolution was actually a proposal for a moratorium on any discussion of the chinese representation issue, which the U.S., of course, feared. BY 1961, this moratorium was beginning to lose its effectiveness and Kennedy realized that a new strategy, not a new policy, was needed to preserve the Nationalists' seat in the Security Council and the General Assembly. 


\section{Initial steps}

The State Department was ordered by Kennedy to study this issue and then present an estimation of the number of votes the U.S. could rely on to side with its objective. In May, 1961, the estimate was sent to McGeorge Bundy, Kennedy's National Security Assistant. The report agreed with the President's thinking; the moratorium was indeed losing its effectiveness. A growing number of nations were beginning to come to the conclusion that keeping Peking out was unrealistic. The report cited the need for new tactics, something that protected the image of the U.S. Most of the nations, according to the report, believed in the "two-Chinas" idea which would allow both Chinese governments to be seated. ${ }^{I}$ This was similar to the proposal put forth by Chester Bowles, but Kennedy was apprehensive about the idea.

The President must have blanched when he read how the other nations were thinking, but he may have also realized that the U.S. was indeed hurting itself by constantly appearing as the leader of the opposition on the china question. This stance would not be conducive to the administration's efforts to influence third world nations. In effect, this meant kennedy now needed to propose a new strategy, one that protected U.S. interests while also protecting its image.

${ }^{1}$ Department of State Memorandum, May 24, 1961. Declassified February 5, 1975, (Washington; D.C.: Carrollton Press, Inc., 1976), Abstract 767-D. 
Kennedy believed that any international gains from actively supporting the admission of the Chinese Communists would be severely outweighed by the political uproar in the U.S. Arthur M. Schlesinger, a White House Assistant, quoted Kennedy from this period as concluding "But if we lost the fight, if Red China comes into the U.N. during our first year in town...they'11 run us out. So as far as this year is concerned, you (Stevenson) must do everything you can to keep them out." 2 Another historian, Donald Lord, reinforced Schlesinger, maintaining that Kennedy acted in a manner that would stop the Communists from taking a seat in the U.N., fearing the political repercussions. ${ }^{3}$ other scholars, including Kenneth Young, believe Kennedy did indeed look for a major change in policy in relation to the U.N. question, but balked on the issue due to the political climate in the U.S. ${ }^{4}$

All three scholars believe Kennedy was looking to change policy, not just tactics. However, Kennedy never illustrated this. He may have spoke in private of this, but he never put his thoughts into action.

Kennedy remained worried about public opinion in relation to the U.N. question. Most of the population was opposed

2 Arthur M. Schlesinger Jr. A Thousand Days (New York: Fawcett Premier, 1965), pp. 446-447.

3 Donald Lord John F. Kennedy: The Politics of Confrontation and Conciliation (Woodbury, New York: Barron's, 1977), p. 226 .

${ }^{4}$ Kenneth T. Young, Negotiating with the Chinese Communists (New York: McGraw-Hill, 1968), p. 240. 
to the idea of allowing the Chinese Communists into the U.N. However, most of these same people agreed that the U.S. should go along with the U.N. if the Peking government was granted admission. ${ }^{5}$ Thịs mixed opinion presented Kennedy with several alternatives. The administration's alternatives included the options: 1. to continue the existing policy of lobbying against the People's Republic; 2. to advocate the "two-chinas" proposal; 3. to let the General Assembly decide the arrangement as long as the Nationalists remained a separate entity. ${ }^{6}$ The President eventually remained tied to the first alternative, refusing to change neither tactics nor policy.

on the same day the State Department delivered its report on the voting estimates in the U.N., Kennedy met with Rusk and Stevenson. This meeting was a discussion of the policy the administration should adopt on the China issue in the U.N. What Kennedy wanted was a strategy that would protect the status quo, keeping the Nationalists in and the Communists out. At one point, Kennedy confronted Stevenson and asked him if he, Stevenson, wanted the Peking delegation to be seated in the General Assembly. Although Stevenson had previously called for the admission he refused to battle the President at

${ }^{5}$ Gerry Ruth Sack Tyler, "A Contextual Analysis of Public opinion Polls: The Question of Admission of Communist China to the United Nations" (Ph.D. dissertation, Yale University, 1972), p. 114 .

${ }^{6}$ William Bayer and Neyland Akra, "The United States and the Admission of Communist China" Political Science Quarterly 76 (September, 1961): 342 . 
this time and meekly answered no to the question. This gave Kennedy the assurance that all present supported his policy and he told the two men that, above all, the integrity of the Nationalists had to be protected, and their U.N. seat preserved. 7 In concluding the meeting, Kennedy reiterated his anxiety over this issue and the potential trouble it could cause the administration in 1964 .

The relationship between the United States and Taiwan reflected Kennedy's policy of caution. The President was unsure of himself in his relationship with Chiang Kai-shek. There was always subtle antagonism in their letters, a mutual feeling of uneasiness. However, Kennedy, due to political problems, could not turn his back on the Generalissimo. Still, even though Kennedy looked to maintain the status quo on this issue, he had his hands full with Chiang. On April 1, 1961, Chiang wrote Kennedy, expressing his personal distaste for the "two-Chinas" proposal. 8 Kennedy, in replying to the Generalissimo, maintained that "one of our major objectives in the United Nations is the maintenance of the status of the Republic of China as a member of the organization", but warned Chiang that Peking was gaining allies around the world who could potentially vote Peking in and Taiwan out. ${ }^{9}$ In essence,

7 Meeting Minutes, May 24, 1961. Box 22, National Security Files, John F. Kennedy Library Archives, Dorchester, Massachusett

${ }^{8}$ Chiang to Kennedy, April 1, 1961. Box 113A, President's Office Files, John F. Kennedy Library Archives, Dorchester, Massachusetts :

9 Kennedy to Chiang, April 17, 1961. Box 113A, President's Office Files. 
Kennedy was telling Chiang that the U.S. was not changing policy, rather strategy.

Chiang had been perceptive when he told kennedy that he was aware that the new administration was looking at the "twoChinas" proposal, but he was wrong to think Kennedy would allow it to be accepted. Kennedy looked at this proposal not as a change in policy, but as a means of maintaining the status quo.

The reason Kennedy looked at this proposal was due to an article that had appeared in Look magazine in January, 1961. Although it might seem unorthodox for Kennedy to be influenced in policy by a magazine article, this particular article was exceptional. Look had obtained a special visa from the State Department that allowed Edgar Snow to travel to the Chinese mainland. Snow had Known Mao and Chou prior to the 1949 revolution and he wished to go back to China to see how much it had changed under the communist government. While in China, Snow interviewed both leaders, accepting their rule of no quotes. Chou did make an exception to the rule in order to clarify one point. He told Snow that the American policymakers should forget the idea of two separate Chinas since Taiwan was an internal issue, one that would be solved by the Chinese. 10 In general, the snow article presented the Chinese leadership as very anti-American. Both men lambasted the U.S.

10 Edgar Snow, "A Report From Red China" Look 25 (January $31,1961): 91$. 
for trying to meddle in chinese affairs.

After reading this article, Kennedy realized that Peking would never accept the "two-Chinas" proposal. This meant he could allow it to be accepted by the General Assembly and not have to worry since Peking would refuse the seat. In turn, this would improve the image of the U.S.

It is important to remember that Kennedy liked to tell administration officials that he found the existing U.N. policy silly, claiming that he was "looking toward some change, in our policy of regarding the government in Taiwan as the true government of all China."11 -However, Kennedy also maintained that he could not turn from the existing policy due to political consequences. He had to preserve the Nationalists' seat in the U.N. or face the wrath of Congress and the China Lobby. In the end, he moved away from his "smoke-screen" strategy and maintained the policy of postponing the U.N. issue.

By the summer of 1961, Kennedy began to lose his nerve on this strategy. The nagging question remained: What if the Chinese Communists accepted the idea of two separate Chinas and took a seat in the U.N.? To Kennedy, this was an unacceptable risk. By September, the proposal calling for the acceptance of the "two-Chinas" resolution was now discarded. Kennedy was now looking to turn from this policy, hoping to go to a safer plateau on the U.N. issue. The proposal

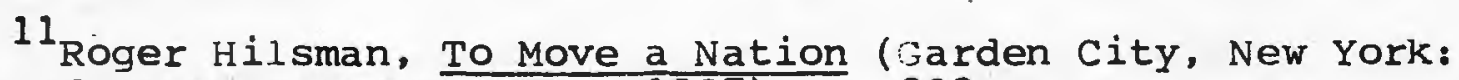
Doubleday and Company, Inc., 1967), p. 303. 
he finally accepted called for creating a resolution in the U.N. that would make the China issue an "important question." The "important question" resolution "expressed the readiness of the assembly to consider the credentials of the People's Republic of China, as a member of the United Nations." 12 BY adopting this resolution as his strategy, Kennedy once again allowed the China issue to be postponed. This resolution did nothing more than call for a five-nation group to study the question of Chinese representation; there would be no vote on their findings until 1962 at the earliest. ${ }^{13}$ The President was now backing away from any proposals that were politically dangerous and moving back to the Eisenhower policy, albeit under a different name. Despite his private statements that talked of the contrary, Kennedy remained with the policy he inherited.

\section{Bracing For a Storm}

Although it is clear that Kennedy was never serious about altering U.S. policy over the China question, there were individuals who feared that the new President might. In May of 1962, Kennedy met with Henry Luce, one such individual. Owner of Time-Life Corporation and long-time proponent of Chiang's government, Luce was anxious to hear of Kennedy's

12 Proposed United Nations Resolution, July, 1961. Box 113A, President's Office Files.

${ }^{13}$ Rusk to Kennedy, July 31, 1961. Declassified February 5, 1975, (Washington, D.C.: Carrollton Press, Inc., 1976), Abstract 767-E. 
plans for the U.N. question. Kennedy, hoping to express to Luce that his goal was identical to Eisenhower's, told Luce the same thing he told Chiang in April. This included the basis of his policy - retaining the Nationalists' seat. The only difference was the means of attaining the goal. During their conversation, the President explained to Luce that the U.S. was hurting itself by actively opposing Peking's admission. Luce was assured by Kennedy that the Nationalists' seat would be preserved. 14

According to an oral history interview at the John F. Kennedy Library, Luce agreed with the administration's minutes of this meeting. He stated that Kennedy pointed out to him that the U.S. could be beaten using the old strategy. All Luce could offer as a way of suggestion was continued support for Chiang and the maintenance of the hard line against Peking. 15

In the fall of 1961 Kennedy moved further away from any new proposals on the U.N. question. He did not want to lose on this issue nor did he want to antagonize his political enemies. This led him to reconsider his options and to all out support for Chiang. On two occasions, Kennedy and his assistant Bundy, spoke of the need to maintain Chiang's government. On October 11, Bundy sent a memorandum to a fellow staff member

${ }^{14}$ Conversation with Luce, May 24, 1961. Box 113A, President's Office Files.

15 Oral History Interview of Henry R. Luce. Oral History Collection, John F. Kennedy Library Archives, Dorchester, Massachusetts. 
citing the President's willingness to "give private reassurances to the Generalissimo that if any time a U.S. veto is what will be effective in preventing Chinese communist entry into the U.N. the U.S. will use the veto."16 on october 16 , Kennedy himself reiterated this policy to Bundy, assuring his assistant that the administration could ill-afford to lose on the representation question. ${ }^{17}$ As time progressed, Kennedy became less willing to take chances, refusing to open himself up for any political attacks.

\section{The Kennedy Legacy}

In retrospect, the Kennedy policy on this issue was one of caution and near paranoia. Although he privately spoke of creating a new policy on this issue, realizing that the existing policy was unrealistic, Kennedy failed to take the first step. He did not change policy, but he did change the means of attaining the existing goal.

The administration saw the U.N. issue as the first test of its ability to act against Peking. By setting a precedent on this issue, Kennedy was able to avoid any political criticism from the like of the China Lobby and Congress. But Kennedy was over-reading in his fear. True, his political foes were formidable, but it is questionable if they could have done as much as Kennedy feared. In addition to this, the

${ }^{16}$ Bundy to Cline, October 11, 1961. Box 22, National Security Files.

17 Kennedy to Bundy, october 16, 1961. Box 22, National Security Files. 
public was willing to accept the chinese Communists in the U.N., if Peking had the support of other nations.

The Kennedy administration was correct in seeing this as its first test on its China policy. This issue did set the tone for the administration's policy towards the People's Republic, but the tone created was highly negative. This tone relected an administration led by a President who was shortsighted and unwilling to take the initiative in rationalizing the American attitude towards the government of Peking.

Problems arose from this policy and hurt the remainder of the administration's Asian plans. While Kennedy spoke publicly of keeping the door open to the Chinese, and privately of his dislike for the existing policy, he was, in reality, acting in a manner contrary to each stance.

It would be foolish to criticize Kennedy for not actively supporting the admission of Peking in 1961. The point is that Kennedy, instead of pursuing a policy that once again blocked the Chinese entry into the U:N., should have let the issue evolve by itself. If the chinese had been admitted, so be it; the administration should have been wise enough to accept the reality of the situation. 
THE SINO-SOVIET SPLIT

The Administration and Communism

John Kennedy matured politically as a member of both houses of Congress in the 1940 's and 1950's. The President and his advisors, most of whom had also matured in the same era, drew upon their past experiences as a source for creating foreign policy for the $1960^{\circ} \mathrm{s}$. In effect, the New Frontier reflected this as the Kennedy administration sought to actively combat communism. Specifically, Kennedy, Rusk, Robert MCNamara, as well as MCGeorge Bundy, all saw the threat of communism in the true ideals of the Cold War. Included in this perception was seeing all communist nations as monolithic in nature. This type of thinking had been part of American diplomacy since 1945 when the Chinese Communist Party was seen by the Truman administration as a mere extension of the Soviet Union. Despite Stalin's explanation regarding the nationa1istic tendencies of the Peking regime, American policymakers in the $1940^{\prime} \mathrm{s}, 1950^{\prime} \mathrm{s}$, and into the 1960's saw the two communist nations as monolithic in ideology and in policy. Only after several years in office did the Kennedy administration realize that this perception was incorrect. Even though American leaders finally came to grips with the dif- 
ferences evident among communist nations, the administration failed to see this as a means of creating a new China policy, choosing instead to hold onto the old policy to a greater extent.

\section{Initial Reactions}

Disagreements between the Soviet Union and the Pejople's Republic began to occur on a regular basis in the latter $1950^{\prime} \mathrm{s}$. These disagreements generally revalved around foreign policy. Each side reflected a different understanding of Lenin's philosophy on communist revolution. Following the death of Stalin in 1957, specific issues revealed these differences. When Nikita Khrushchev emerged as the new Soviet leader, the new Premier advocated a less militant foreign policy towards the West. The Chinese Communists, under the leadership of Mao and Chou En-lai, opposed Khrushchev on this policy, maintaining that the west could not be defeated through relaxation of hostilities. Within this general argument emerged several subtopics where ideological differences grew more apparent.

The significance of the dispute between the Soviets and the Chinese proved that the communist bloc was not as united as America thought. As the 1950 's ended, the Chinese were beginning to break away from the uniform policy put forth by the Russians, but this was not always the case. Immediately following the Chinese revolution in 1949, the Peking government was willing to follow the Soviet lead, allowing Stalin to dictate policy for both nations. In short, the Soviets acted very much like the big brother to the new chinese government. 
The strongest element of the relationship was the policy of viewing the U.S. as the enemy of world-wide communism. ${ }^{1}$

Stalin's policy advocated hostility towards the U.S. and the Chinese were willing to accept this policy due to their bitter feelings towards the Americans after 1949.

When Khrushchev denounced Stalin and his policy of hostility, the Chinese were not willing to follow suit. The new Soviet leader wanted a relaxed relationship with the U.S., hoping to create detente or "peaceful co-existence." In turn, Khrushchev feared Chinese hostility towards the West would disrupt these hopes.

Included in this disagreement, on the Chinese side, was the issue of nuclear weapons. The Chinese were actively pursuing a program that would have allowed them to join the "nuclear club". "They were wary of Khrushchev's policy of detente because they feared that the Soviets would be more willing to negotiate an arms control agreement with the U.S. rather than to assist them on developing nuclear capability.

As mentioned above, this dispute went virtually unnoticed in the U.S. throughout the $1950 . \mathrm{s}$. The first report on the dispute appeared in January, 1961. The Central Intelligence Agency had obtained information in October of 1960 , but it was rever presented until two days prior to the Kennedy inauguration. Most of the report's analysis came from the re-

${ }^{1}$ CIA Report, April 1, 1961. Box 21, National Security Files, John F. Kennedy Library Archives, Dorchester, Massachusetts. 
sults of the Conference of Communist Nations that was held in June, 1960. The report concluded that the Chinese Communists denounced the "formation of the peaceful road to communism" which Khrushchev had advocated. ${ }^{2}$ In addition to this, the Chinese also denounced the Soviets for threatening the Polish government with military force in the 1950's. In 1956, the Soviets had moved to censure the Poles, something with which the Chinese did not agree. This was an illustration of how sympathetic the Chinese were towards independent action within the communist bloc. The CIA also cited Khrushchev as willing to strike back at the Chinese, criticizing Chinese aggression towards India in $1959 .^{3}$ This was an illustration of the Soviet fear of Chinese adventurism and an example of Soviet dislike for an attack on a Russian ally. The report concluded that Khrushchev was willing to negotiate with the U.S., citing the Soviet Premier's statement that 1960 was "the year in which the aspirations of humanity for a world without armed forces and without war" was possible. 4 The Chinese, desperately striving to create a nuclear arsenal, were not over-joyed with this statement.

A second study conducted by the CIA was presented on the first of April, 1961. This report was more analytical, em-

${ }^{2}$ CIA Report, January 19, 1961. Declassified September 14, 1979, (Washington, D.C.8 Carrollton Press, Inc., 1980), Abstract 339-A.

${ }^{3}$ Ibid.

${ }^{4}$ Ibid. 
phasizing the effect of the dispute on the United States. It concluded that the split between the Soviets and the Chinese was growing, the main reason for the growth being Khrushchev's willingness to negotiate with the U.S. The core of this dispute was the nuclear issue. The CIA declared, "They (the Chinese) are not worried about the Nth countries; they intend to be one." 5 The report estimated that Mao would not be willing to enter into any arms talks without the capability to produce weapons. Mao, insisted the CIA, "intends to use the resulting leverage to demand the return of Taiwan, diplomatic recognition, and perhaps admission to the U.N."6 What worried Mao was the speed of the Chinese developmental program; without Soviet assistance the program would falter.

All of the above conclusions must have had a sobering effect on Kennedy and it justifies his anxieties over Peking. Yet despite the realization of the Chinese threat, Kennedy did nothing to better relations with Peking. Instead, he chose to increase his policy of containing the chinese. This was reflected in his willingness to increase American involvement in vietnam.

Publicly, Kennedy refused to make any significant statements on the sino-Soviet split in the early months of his tenure. In March, 1961, when asked about his thoughts on the dispute, he replied that he was not very enthusiastic about

${ }^{5}$ CIA Report, April 1, 1961. Box 22, National Security Files. ${ }^{6}$ Ibid. 
the situation. Later, in the Fall of 1961, he was again asked for his feelings on the split and he stated that there was not enough concrete data to truly assess the conflict. 7 The question is how much data did he need to consider it concrete? The April CIA report alone was over sixty pages, complete with a history of the dispute and its significance for the U.S. There was enough data; what was lacking was a positive response from the administration, something besides a policy of continued containment.

\section{American Response.}

Kennedy and his administration began to closely watch the progression of the Sino-Soviet dispute in the latter part of 1961. In addition to the two CIA reports, the administration prepared its own analysis of the split, trying to come to some conclusions. In general, the administration's analysis went beyond the CIA's perception and indicated that the Chinese were now the long-term threat to the United States, surpassing the soviets in hostility and militancy. ${ }^{8}$ secretary of State Rusk, for whatever reason, failed to articulate this analysis, stating only that there was "solid evidence of some tensions" between the Chinese and Soviets, and that the United States could do nothing in response to the existing

7 Public Papers of the Presidents of the United States. (Washington, D.C.: United States Government Printing office, 1962), John F. Kennedy, 1961.

${ }^{8}$ Richard Stebbins, The United States in World Affairs, 1961 (New York: Harper and Brother, 1962), p. 219. 
situation. 9 This type of statement, from the State Department leader, indicated a lack of foresight on the part of many within the administration. Rusk saw evidence of the dispute, but failed to formulate a new. policy to reflect the split. It must be concluded that Rusk and the administration did not see the dangers the split presented nor did it see the possibilities that could emerge. Here was a chance for the Kennedy administration to open the door to the Chinese, but kennedy refused to take the initiative. In turn, the door remained closed and tightly secured.

In 1962 the Kennedy administration stepped up its interest in the Sino-soviet tensions. In early January, a state Department Policy Planning meeting was the scene for a presentation by the Far East bureau which concluded that the split was not only real, but that permanent obstacles had now emerged between Peking and Moscow. ${ }^{10}$ In May, Roger Hilsman sent a memorandum to Rusk, indicating a need to come to terms with the issue. Although Hilsman presented a realistic assessment of the dispute; he failed to offer any recommendations for a positive American response. Drawing from intelligence reports, Hilsman maintained that while the two communist nations were deeply divided, both feared a complete break in relations.

$$
{ }^{9} \text { Ibid., p. } 225 .
$$

${ }^{10}$ James C. Thomson Jr., "On the Making of U.S. China Policy, 1961-1969: A Study in Bureaucratic Politics" China Quarterly 50 (Fal1, 1972): 226. 
On this aspect, Hilsman believed that American-Soviet detente would encourage a complete split. 11 Hilsman's conclusion was an accurate one. If Kennedy was going to act in a manner that inxited detente, he had to take into consideration the chinese response. This included any plans for negotiating with the Soviets on nuclear weapons since the Chinese would have to be considered as a potential threat.

A related second point that Hilsman brought up, was the position taken by the two communist governments on future relations with the United States. While Khrushchev was apparently moving towards detente, the chinese continued to assail the Kennedy administration as imperialists. ${ }^{12}$ The Chinese refused to back away from the stalinist policy of hostility. To them, the kennedy administration was an unknown quantity. The Chinese perception was based on general statements by Kennedy and members of his administration. The chinese believed the U.S. was not out to better relations, but rather, to contain the mainland.

A closer look at the dispute is necessary in order to understand the issues within the split at this stage and their relation to the United States. By 1962, the dispute was becoming a three-sided situation. The Soviets, Chinese, and the Americans were all involved, creating a vicious cycle in which

$11_{\text {Hilsman to Rusk, May 14, 1962. Box 1, Personal Papers }}$ of Roger Hilsman, John F. Kennedy Library Archives, Dorchester, Massachusetts.

12 Ibid. 
the Soviets and Americans spun closer together while the Chinese spun away from them. When the Soviets demonstrated a willingness to move closer to the U.S., the Sino-Soviet dispute grew and the Chinese began to appear as the "bad guys" in the relationship. The cycle would continue when China would denounce the Kennedy administration and Khrushchev. An example of this was in August, 1962, when the Soviets refused to give the Chinese any new nuclear assistance or technology, agreeing with the Kennedy administration that both nations should try to prevent further proliferation of nuclear weapons. 13 This infuriated the Chinese who quickly denounced Khrushchev. In October, after the Cuban missile crisis, Peking increased criticism of the Soviet leadership, insisting that Khrushchev had fallen to a "paper tiger."

The Soviet Premier was livid over this statement and declared the Chinese were acting Iike "Troskyites" who failed to see the tiger's "nuclear teeth."14 This vicious cycle continued throughout 1962 .

In relation to this, Hilsman openly commented to Rusk about problems associated with the dispute. Hilsman realized that the U.S. could push for detente with the Soviets only at the expense of further isolating the Chinese. ${ }^{15}$ In essence,

${ }^{13}$ Peter H. Juviler and Henry W. Morton, gen. eds., Soviet Policy Making (New York: Praeger Publishers, 1967), "America, China, and the Hydra-Headed opposition", by Robert M. Slusser, p. 220 .

${ }^{14}$ Ibid., p. 228.

15 Hilsman to Rusk, May 14, 1962, Hilsman Papers 
the Chinese would become an isolated state with a nuclear arsenal. This worried Hilsman and while he called for action, he could not recommend any to Rusk. This was the dilemma for the administration - it believed it had to act, but it was not quite sure how.

Walter Rostow, Chairman of the Policy Planning Cancil at the State Department, exemplified this dilemma. In the January meeting of the Council, Rostow, along with Rusk, expressed an inability to come to terms with the Sino-Soviet dispute. According to Rostow, "No one knows what to do about it. Is it good or bad for us?" 16 He finally deduced that the split was "essentially a favorable event for us," but could not assess whether the U.S. wanted a clean break between Moscow and Peking. 17 At the same meeting, Rusk again offered no analysis and called for further study by the state Department. One year after the first full report on the dispute, the Kennedy braintrust at the state Department, still could not formulate a policy in response to the situation.

While Rostow can be commended for being one of the first members of the administration to admit that monolithic communism was a fallacy, he was also unwilling to see the implications of this discovery, choosing instead to maintain a rigid stance against both sides of the dispute. Rostow be-

${ }^{16}$ Policy Pianning Council, January 2, 1962. Personal Papers of James C. Thomson Jr., Box 15, John F. Kennedy Library Archives, Dorchester, Massachusetts.

17 Ibid. 
lieved, in conjunction with the two CIA reports, that the Soviets and Chinese might be in the midst of a quarrel with each other, but, in the end, the "Reds were still fundamentally hostile to the West." 18 Rather than seeing the split. as something positive, as he had declared in January, Rostow now backtracked into seeing the dispute as insignificant. Rostow's thinking illustrated the lack of willingness to move ahead within the Kennedy administration. Here was a chance for the U.S, to create better relations with China, but the administration chose instead to maintain the hard line of containment.

The initiatives that did emerge from the administration proved to be even more rigid than the existing policy. The President now saw the Chinese as the real threat to world peace, stating, "we could be worse off...if the Chinese dominated the communist movement, because they believe in war as the means of bringing about the communist world."19 Publicly, Kennedy maintained that there was little the U.S. could do over the dispute, but in actuality, the administration was acting by moving closer to the soviets. While accommodating himself with the Russians, Kennedy was also increasing his policy of containment against the chinese. By doing this, the

18 John Lewis Gaddis, Strategies of Containment (New York: Oxford University Press, 1982), p. 209.

19 Public Papers of the Presidents of the United States (washington, D.C.: United States Government Printing office, 1963), John F. Kennedy, 1962, p. 900. 
President was going against the private remarks he had made concerning the new direction he hoped to take in relation to the China policy.

$\therefore$ While Kennedy called the Chinese the greatest threat to world peace, he was actually misleading the American public. In reality, the Chinese posed a potential threat, not a present one. In 1962, the Chinese were still two years away from detonating their first nuclear device. One observer saw china as containing both a billion "human bees" and the potential to create a "nuclear beehive". 20 But this was China's potential, not its present situation. The Chinese, in 1962, were a "have-not" nation in terms of industrial capability, unable to sustain an expanded military operation. 21

Kennedy should have emphasized the word potential and he should have taken steps to alleviate that potential threat. However, he chose to maintain the policy of containment rather than create a policy of negotiation. The administration was was consistent on this issue in relation to its overall China policy. Kennedy refused to see the implications of not developing a long-range strategy in response to the Sino-Soviet dispute.

20 Kenneth Young Memorandum, November, 1960. Box 121 , President's Office Files, John F. Kennedy Library Archives, Dorchester, Massachusetts.

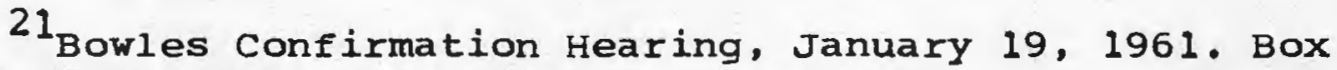
7, Personal Papers of James C. Thomson Jr. 
CHAPTER IV

THE POLICY OF CONTAINMENT

Willing To Act

The first three chapters of this study have illustrated what John Kennedy was not willing to do in terms of his China policy. He refused to re-evaluate the policy as a whole, he backed away from allowing the United Nations to accept the "two-Chinas" resolution, and he refused to see the Sino-Soviet split as a means of creating better relations between the U.S. and Red China. This chapter will demonstrate what Kennedy was willing to do in order to implement a policy. One cannot conclude that kennedy did nothing to alter relations between Washington and Peking, but it should be stressed that what he did do in this area actually pushed the two apart, relations growing colder. When it came to confronting and containing Red China, John Kennedy was an eager participant.

The policy of containing the Chinese centered around two issues: the Laos crisis in 1961 and 1962, and the status and protection of India. Both issues were focal points for Kennedy's policy. In 1963, vietnam would join this list. Kennedy was out to show the Chinese that he would not be bullied and that American policy was stronger than before. In essence, Kennedy reinforced the Eisenhower policy. 


\section{Laos}

Kennedy inherited a delicate situation with the Laos crisis. The circumstances in Laos could not be described as anything other than a prime exampie of Cold War dogma and action. It was a situation that neither the U.S. nor the communists could hope to win without a major military escalation.

In 1960, Eisenhower warned Kennedy of the seriousness of the situation, cautioning the new President that there was a distinct possibility that American troops would be needed in Laos to avert the fall of the pro-American government to communist backed forces. ${ }^{1}$ Kennedy welcomed this challenge, hoping to draw upon his cold War experience and confront the communist threat. Outside of the Bay of Pigs, Laos became the administration's first "hot spot." The administration dove into the fray, seeking quick and favorable results for the U.S. Kennedy saw Laos as the chance to implement the policy of containment. And this policy would be directed at the chinese Communists.

Eisenhower, when he advised Kennedy of the severity of the crisis, may have been informing his successor that the American effort in Laos was not going very well. The Republican administration had been giving strong support to the pro-American government, the Royal Lao, headed by Prince Boun Oum and General Nosavan Phoumi, since 1954. However, in his

\footnotetext{
1 Theodore Sorenson, Kennedy (New York: Harper and Row, 1965), p. 640 .
} 
desire to support the Royal Lao, Eisenhower had cased the neutral faction, headed by Souvanna Phouma, to look to the Pathet-Lao, the communist force, for assistance. ${ }^{2}$ Kennedy, after entering office, soon realized that the situation in Laos was not going in the right direction for the U.S. The Royal Lao was deteriorating in strength and in influence. The Soviet Union was sending aid to the Pathet Lao which was beginning to win battles on a regular basis over the Royal Lao Army. Members of the Royal Lao forces demonstrated to the U.S. that they lacked the determination to win the civil war. The Pathet Lao was quickly becoming the dominant force in Laos, and Kennedy had to act in order to counter this.

All of this left Kennedy in a position where he had to re-evaluate his policy. Either he could continue to support the Royal Lao, increasing American aid or possibly sending troops to Laos, or he could begin preparations to initiate the process of creating a new nation, a neutral Laos. If Kennedy wanted an independent Laos, one under the leadership of a coalition government, he had to be willing to negotiate. The President was correct when he acknowledged the strength of the Pathet Lao who had the power to eventually overrun the Royal Lao, something that Kennedy did not want to happen. If this did occur, Kennedy realized that U.S. commitments to SouthEast Asia could be severely jepordized. Specifically, if

2 The Pentagon Papers, Gravel Edition, Volume II (Boston: Beacon Press), p. 22 . 
Kennedy allowed the Royal Lao to fall, then, in his mind, China might see the U.S. as unwilling to live up to its commitments in the region. Kennedy believed he had to remain firm in Laos, even though he was considering negotiations. He emphasized that "we cannot accept a Communist military expansion backed by China into this critical area." ${ }^{3}$ The policy of containing China and protecting American interests in Southeast Asia remained the Kennedy doctrine.

In Laos, the Soviets were the primary supplier to the Pathet Lao, with Peking and Hanoi offering various forms of aid. Although China was not acting in as great a capacity as the Soviets, Kennedy still feared Peking more than Moscow in Laos. He maintained that China was the great threat in Asia, stating in his first State of the Union Adress, "In Asia, the relentless pressures of the Chinese Communists menace the security of the entire region..." 4 . Kennedy was also an advocate of the then popular "domino theory", keeping consistent with the Eisenhower policy. Both Eisenhower and Kennedy believed a communist victory in Laos would be the first step towards an eventual communist Southeast Asia. Short of war, Kennedy felt he had to act to ensure against this.

3 Kennedy to Prime Minister Nehru, April 16, 1961. Box 111, National Security Files, John F. Kennedy Library Archives, Dorchester, Massachusetts.

${ }^{4}$ Public Papers of the Presidents of the United States. (Washington, D.C.: United States Government Printing Office, 1962), John. F. Kennedy, 1961. p. 23. 
Historian Hugh Toye is quite supportive of Kennedy's actions to try and reach a peaceful and negotiated settlement in Laos. Toye saw Kennedy, by March 1961, as moving further away from the Eisenhower policy of military assistance to the Royal Lao, and towards the policy of negotiations to mitigate the crisis. ${ }^{5}$ william Leuchtenberg, a fellow historian, agreed with Toye, noting Kennedy was "more willing than Eisenhower to countenance a solution in Southeast Asia which would neutralize the region and less insistent on outright triumph for the West." 6 A third scholar, Frances Fitzsimons, interpreted the Laos policy a bit differently. She agreed with Toye and Leuchtenberg on the point that Kennedy was indeed disappointed with the military status in Laos, but she contended that kennedy was calling for negotiations without reneging on a policy of containment, something Toye and Leuchtenberg failed to deal with. ${ }^{7}$ According to Fitzsimons, Kennedy was not willing to back away from U.S. commitments in Laos and let the Pathet Lao take the nation over. Thus, she contended, he chose negotiations as an alternative still within his policy of containing the Chinese.

The three scholars agreed on Kennedy's means, but only

5 Hugh Toye, Laos: Buffer State or Battleground (New York: oxford University Press, 1968), pp. 165-166.

6 John F. Kennedy and the New Frontier. Aida Donald, gen. ed., (New York: Hill and Wang, 1966), "Kennedy and the End of the Post-War World" by William Leuchtenberg, p. 127.

7 Frances FitzSimons, The Kennedy Doctrine (New York: Random House, 1972), pp. 83, 92 . 
- $\quad-44-$

Fitzsimons perceived his goal - a policy of continued containment - correctly. While Toye and Leuchtenberg seemed to see Kennedy as willing to "back off" in Laos, in reality he was doing what he thought was right in order to protect American interests.

This is not to conclude that Kennedy was not interested in a neutral Laos. The President believed in this goal, but supported measures that would protect his policy of containment. To illustrate Kennedy's beliefs, a series of documents from the time period can be analyzed. In March, Kennedy began to correspond with India's Prime Minister Nehru, asking him for suggestions and assistance while keeping the Prime Minister abreast of the situation in Laos. The theme of these letters was a belief in a neutral Laos, but also a desire to see the Royal Lao retain predominance. In one letter, Kennedy expressed this desire when he told Nehru that the - U.S. would never accept a coalition government that was dominated by the Pathet Lao. ${ }^{8}$ In effect, Kennedy did want a coalition, but only one that would be pro-American.

\section{Alternatives}

Kennedy was able to gather support for the policy from administration personnel and members of congress. The first recommendation on the Laos crisis, after Eisenhower, was from

${ }^{8}$ Kennedy to Nehru, March 23, 1961. Box 111, National Security Files. 
Senator Michael Mansfield. A former colleague in the Senate, the fellow Democrat sent a memorandum the day after Kennedy's inauguration. Mansfield was quite perceptive about the circumstances in Laos, citing the absurdity of an American policy that unilaterally provided military assistance to the Royal Lao government. 9 Another supporter of a neutral Laos was the American embassy in Laos, but this support, in essence, was clearly aligned with Kennedy's policy of a pro-American coalition. In February, a State Department telegram from the embassy maintained support for a coalition government, but emphasized that the coalition's "composition should not be made at the expense of political stability."10 A third source of support was Secretary of State Rusk. 'Rusk stressed the idea of a neutral Laos, but believed that the Soviets should be made aware that this was the only alternative to a major military confrontation. 11 The implication here was that the U.S. was willing to talk, but also willing to fight over Laos. While some members of the administration advocated a policy of negotiations, other personnel called for a possible military solution. Kenneth $T$. Young, a member of the State Department, presented two separate reports on Laos to Kennedy.

${ }^{9}$ Mansfield to Kennedy, January 21, 1961. Box 121, President's Office Files, John F. Kennedy Library Archives, Dorchester, Massachusetts.

${ }^{10}$ American Embassy, Vientiane, to washington, February 14, 1961. Box 121, President's Office Files.

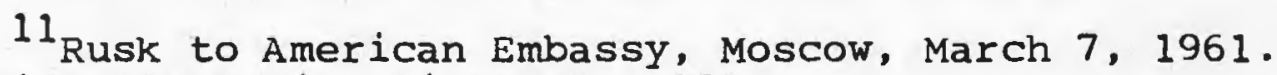
President's Office Files, Box 121 . 
The first analysis, presented in November, 1960, was extremely militant in its makeup. This report was centered on the Southeast Asia region in general, and the Chinese Communists in particular. Young agreed with Kennedy that "Red China (was) fast becoming the power that count(ed) in East Asia."12 According to Young, a strong stand by the administration in the region was the only way to impress upon Peking that the .U.S. was taking its commitments there seriously. The title of Young's report declared that this was a "new approach" to the problems of Southeast Asia. In reality, this approach was a compliment to the Eisenhower policy and consistent with the policy of containment. One example of this was Young's contention that the South East Asia Treaty Organization (SEATO) needed to be phased out and replaced with a multi-national military planning group. ${ }^{13}$ This was Young's interpretation of a "new approach". In actuality it was a continuation of the containment policy. This was the theme of the New Frontier.

In the spring of 1961 , Young presented his second report to Kennedy. This analysis dealt specifically with Laos. Although Young did not see the feasibility of war in Laos, he did retain his hard line against Peking. To Young, the Chinese still had to be made aware of the U.S. commitment to Laos. He maintained that the soviets would have to prod the

12 Young to Kennedy, November, 1960. Box 121, President's Office Files.

13 Ibid. 
Chinese to negotiate over Laos or leash Peking. 14 Again, Young was in agreement with Kennedy as both saw the Chinese as the primary threat in Laos. Overall, this second report was not really different from the first. Both were hostile to Peking and each maintained the containment policy.

MCGeorge Bundy was a member of the hard line group over Laos. Bundy proposed that the U.S. needed to act in order to impress the Chinese, illustrating the American commitment to the Royal Lao. 15 Concurring with Young, Bundy saw SEATO as weak, outdated, and useless to the American effort in Laos. Bundy knew Kennedy did not want to appear weak over Laos and played up to this anxiety. Kennedy's fear would increase after the Bay of Pigs affair in April. If things continued to go poorly for the U.S. in world affairs, thought Kennedy, then the administration would find Peking willing to test the Americans in Asia.

Prior to the organization of the Geneva Conference, the administration prepared for the possible breakdown of the cease-fire. In May, 1961, a series of National Security Council meetings were held to discuss the crisis and prepare for the possible introduction of American troops into the region near Laos. Kennedy made it clear to the members of the Council that he was prepared to deploy troops into Laos as well

14 Young to Kennedy, Apri1, 1961. Box 121, President's Office Files.

15 Bundy to Kennedy, February 7, 1961. Box 121, President's Office Files. 
as Thailand in order to contain the communist threat. ${ }^{16} \mathrm{~A}$ second meeting consisted of a briefing by the Joint chiefs of Staff on the subject of military alternatives in Laos. After hearing their report, Kennedy instructed them to continue planning such operations. 17 A third meeting was held on May 11 and Kennedy declared to the council that the U.S. would intervene to prevent a communist Laos if the cease-fire broke or the talks at jeneva failed. 18 The conference at Geneva began five days later, with Kennedy remaining prepared to act with military force if necessary.

Prior to the end of the Geneva Conference, Kennedy began to doubt that the nations would come to terms over Laos. In May, 1962, he professed a willingness to begin unilateral operations in Laos if the cease-fire broke. 19 In effect, Kennedy was unwilling to take any chances on Laos, believing that his image would be ruined if the nation fell into the hands of the Pathet Lao. He wanted to make sure American interests were protected. In calling for elections in Laos, Kennedy maintained that they would only be held when it was certain that pro-American elements were in a position to defeat the

${ }^{16}$ National Security Council Meeting, May 1, 1961. Box 313, National Security Files.

17 National Security Council Meeting, May 4, 1961. Box 313, National Security Files.

${ }^{18}$ National Security Council Meeting, May 11, 1961. Box 313. National Security Files.

19 National Security Council Meeting, May 24, 1962. Box 336, National Security Files. 
communist forces in the elections. ${ }^{20}$ Kennedy was willing to disregard democracy in return for a stable, pro-American government in Laos.

\section{Review of the Laos Policy}

The Kennedy policy in Laos was indicative of the administration's overall Asian strategy. Kennedy maintained "that with the rise of Communist power in China, combined with an expansionist, stalinist philosophy..." there was a need to "contain the expansion of communism in Asia so we do not find the Chinese moving out into a dominate position in Asia. ${ }^{21}$ This was the core of the New Frontier, an active policy against the communist threat.

Kennedy entered office faced with a situation in Laos that was polarized into right versus left, with the neutrals vacating the center to join the Pathet Lao. Much of the blame for this must be placed on $\mathrm{E}$ isenhower, due to his refusal to look for the neutral solution in Laos. Kennedy believed he had to act since his policy planners maintained that Laos was one of the four "roads" from China into Southeast Asia that had to be secured in order to maintain the status quo. 22

\section{${ }^{20}$ Ibid.}

${ }^{21}$ public Papers of the Presidents of the United States. (Washington, D.C.: United States Government Printing office, 1963), John F. Kennedy, 1962. pp. 850-851.

22 America's Asia: Dissenting Essays on Asian-American Relations, Edward Friedman and Mark Seldon, gen. eds., (New York: Patheon Books, 1969), "The United States in Laos, 1945$1962^{\circ}$, by Jonathan Mirsky and Stephen Stonefield, p. 286. 
Rather than accepting a truly neutral Laos, Kennedy tended to maintain both the Cold War doctrine and the policy of Eisenhower.

The administration's military plans were indeed formidable. The Navy's Seventh Fleet was placed on alert several times during 1961 and 1962 and troops were sent to Thailand. How far Kennedy was willing to go in Laos is a question open to debate. In October, 1961, the cease-fire in Laos was, at best, fragile. The Royal Lao, fearful. that the U.S. had deserted it, acted in a manner that sought to break the ceasefire and disrupt the talks at Geneva. Kennedy insisted at the time that no matter how the cease-fire was broken, the U.S. was going to intervene militarily. 23

In May, 1962, Kennedy demonstrated how far he was willing to go in Laos. The Royal Lao had succeeded in breaking the cease-fire and crossed the cease-fire line. On May 12, Kennedy accepted a Pentagon plan to act militarily since the cease-fire was now broken. The administration placed the blame on the Pathet Lao, thus rationalizing an American response. The Pentagon plan recommended full support for the Royal Lao (the true perportrators of the crisis), and advocated use of military force "including nuclear attacks on China" if necessary. 24 The pentagon did not want to be bogged

${ }^{23}$ Mirsky and Stonefield, "The U.S. in Laos", p. 297.

${ }^{24}$ Roger Hilsman, To Move a Nation, (Garden City, New York: Doubleday and Company, Inc., 1967), pp. 142-143. 
down in an Asian war and to them, nuclear attacks were the best way to avoid this.

By May 25, the crisis in Laos had passed and the ceasefire was intact once again. The Geneva Conference ended in July and created a provisional government under the leadership of Souvanna Phouma. However, U.S. troops remained in Thailand and played a tangible part in containing China. The administration had been willing to push the Laos crisis to the brink of nuclear war, despite the fact that its own ally had caused the crisis. All of Kennedy's actions illustrated his preoccupation with containing China.

\section{India}

The American relationship with India, in terms of the China policy, was two-fold. In the first instance, India was to American leaders an example of the ability of "free" nations to succeed in Asia. The second phase of the relationship began in October, 1962, when the Chinese crossed the Indian borders.

As a candidate for President in 1960, Kennedy used India as a means of comparing the free world to the communist bloc, specifically to Communist China. In a standard speech, the candidate presented India and China as contestants or comparable entities. To Kennedy, India illustrated "human dignity and individual freedom" while "Red China represent(ed) regimented controls and (a) ruthless denial of human rights and 
freedom. 25 In another speech, Kennedy pointed out that India was a key nation in Asia and that the Nehru government would counter Peking's threat to Asia by serving as a "pole", along with Japan, to balance the threat of communism. 26

As a Senator, Kennedy had proposed a 1959 resolution that endorsed American support for India's five year economic plan. Again, Kennedy saw this as a way to surpass the Chinese who were also in the midst of a series of economic developments. The resolution asserted, "We want India to win that race with China."27 If India did not "win", Kennedy maintained, then the balance of power in Asia would shift against the United States.

Despite Kennedy's policy of increased economic aid to India, the government of Jawaharlal Nehru remained basically neutral. In a way, India was a go-between for the soviets and the Americans. Kennedy accepted India's neutrality, but refused to back away from trying to create a better relationship with Nehru, hoping to eventually sway the Prime Minister to come into the American camp. In effect, this led to the increased economic aid and promises of military assistance if

25 University of New Hampshire Speech, March 7, 1960. Box 1030, Pre-Presidential Papers of John F. Kennedy, John F. Kennedy Library Archives, Dorchester, Massachusetts.

26 Hawaii Speech, August 15, 1960. Box.6, Personal Papers of James C. Thomson Jr., John F. Kennedy Library Archives, Dorchester, Massachusetts.

27 Arthur M. Schlesinger Jr., A Thousand Days (New York: Fawcett Premier, 1965), p. 482 . 
Nehru requested it. However, by trying to induce Nehru with increased aid, Kennedy was beginning to hurt U.S. relations with Pakistan. Kennedy was forced to walk a tightrope in his efforts, to contain China.

The American ambassador to New Delhi was John Kenneth Galbraith, the noted economist from Harvard. He too believed in trying to attract the Nehru government through increased economic aid. Together with Kennedy; Galbraith hoped to bolster the economy of India and keep it competitive with Peking. In turn, India would then provide the administration with a solid ally to help contain China.

A major proponent of this policy was Chester Bowles. Bowles had been ambassador to India in the 1950's and he believed Nehru could help the administration as long as Kennedy did not try to force India to align with the U.S., suggesting, "We should not expect India to abandon its nonalignment policies, nor should we even attempt to press Nehru in this direction." 28 In october , 1962, the Chinese would cross the border into India and solve this problem for Kennedy.

Relations between China and India had been very poor since the rise of border skirmishes in 1959. The area in dispute was known as "pamir knot" and had historically been an area of conflict. ${ }^{29}$ In December, 1961, India's Defense

${ }^{28}$ Chester Bowles, Promises to keep (New York: Harper and Row, 1971), p. 466 .

${ }^{29}$ John Rowland, A History of Sino-Indian Relations (Princeton, New Jersey: D. Van Nostrand Company, Inc., 1967), p. 156. 
Minister, Krishna Menon, publicy stated that his nation would reclaim its lost areas from china "one way or another." 30 Menon always believed India could expect the Soviets to be a deterrance to the chinese and these remarks illustrated this belief. The Nehru government, trying to pressure Peking economically, abandoned a trade agreement between the two nations. India also provoked China by establishing outposts behind the Chinese borders. In the early fall, Nehru announced that these outposts would conduct sweeps of the area to remove Chinese.

It is clear that these actions added to the existing tensions. Heavy fighting broke out in october and the Chinese were on the offensive by November 15. Nehru's forces were clearly weaker than Peking's and the Indian leader put in an urgent appeal to Washington.

Although the fighting came at the worst possible time (due to the proximity in time to the cuban missile crisis), it did allow kennedy to implement his plan for increasing aid to India. Kennedy's willingness to come to India's aid at this time was quite obvious. To temper this enthusiasm, Rusk insisted that the U.S. "should in no way appear in a position of running after Nehru to offer aid, but rather to be responsive as appropriate to his needs. ${ }^{31}$ The embassy in New Delhi agreed

30 Hilsman, To Move a Nation, p. 322.

${ }^{31}$ Rusk to American Embassy, New Delhi, October $20,1962$. Box 11, National Security Files. 
with Rusk, as Galbraith emphasized that the U.S. would appear more controlled if Nehru's request was publicized. 32

It seems as though Kennedy needed to be restrained by Rusk and Galbraith. This was his first opportunity to actively confront the chinese and he hoped to perform correctly. Yet Kennedy had to be restrained because of the delicacy of the situation. The Soviets and the Nehru government were friendly and Kennedy had to be careful not to antägonize the Russians who could then turn and assist the Chinese. The other delicate aspect of the crisis was Kennedy's position with Pakistan. He could not appear as willing to arm India at the expense of India's arch-enemy. Fortunately for the administration, none of this occured.

The reason China attacked when it did is open to debate. Historically, the "pamir knot" had been an area of conflict and this may have simply have been just another outbreak over the region. Another reason could have been the provocation by India in the months preceding the hostilities. Finally, the fighting may have been a result of the SinoSoviet dispute. The chinese may have been trying to intimidate the soviets by attacking India. ${ }^{33}$ For whatever reason, the Sino-Indian. War helped Kennedy implement his containment policy against the Chinese.

${ }^{32}$ Galbraith to Rusk, october 29, 1962. Box 111, National Security Files.

${ }^{33}$ Rowland, A History of Sino-Indian Relations, p. 167. 


\section{Reflections}

The Laos crisis and the Sino-Indian War both forced Kennedy to come to terms with a concrete policy towards the Chinese Communists. Several months after the crisis in India, Kennedy described China as a "Stalinist regime...determined on war as a means of bringing about its ultimate success..."34 And Kennedy decided that the way to deal with this was through the policy of active containment. This was the epitome of the New Frontier. The Kennedy administration was not going to be bullied by the chinese, rather it was going to confront them. The policy was to confront China, hoping to maintain the status quo in Asia.

34 Hilsman, To Move a Nation, p. 339. 
CHAPTER V

THE FOOD CRISIS

\section{2: The Pivotal Year}

To John Kennedy, 1962 was indeed the pivotal year for his policy towards the Chinese communists. This was the year he" had to decide if he wished to take the initiative to bring about better communications between washington and Peking. The alternative was to maintain the existing policy and add stringent measures to combat the emerging Chinese. In the end, Kennedy chose to follow the old policy, increasing American involvement in Vietnam and trying to contain the Chinese Communists.

1962 was a pivotal year for several other reasons. A year had passed since the administration first began to contemplate the China issue, allowing Kennedy the time to decide if he wanted to be more flexible towards Peking and taking the initiative. Secondly, the Cuban missile crisis and its results raised Kennedy's stock in the world. He was in a position of authority and could demand respect for any diplomatic step he took, including approaching the chinese. A third reason marking the significance of 1962 was the state of chinese development at the time. The administration was well aware of the Chinese nuclear program. The President 
spoke publicly of his anxieties over the twin dangers of Chinese hostile policy and these weapons. In relation to this, after Cuba, Kennedy and Khrushcher spoke of the need to negotiate on arms control. Both were well aware of China:s potential in this area and each realized that any disarmament talks would have to include the chinese to be significant and complete. 1962 also included Kennedy's private assurances to administration officials that this was indeed the year for a change in attitude.

Some of Kennedy's actions in 1962 have been discussed in the preceding chapter. In the next two chapters, the focus will be on two specific issues that reflected Kennedy's course of action, or rather inaction. The first will be on his policy towards shipments of food grain to the Chinese. The following chapter will deal with the 1963 Test Ban Treaty and how Kennedy looked to include. the Chinese in the framework of the agreement. Both issues will once again reflect the President's cautious and hesitant attitude towards Peking, bringing into question Kennedy's sincerity when he spoke of the need for a ner China policy.

\section{Factions within}

After its first year in office, the Kennedy administration began to divide and form two solid factions in relation to the direction in which the China policy should proceed. On the one hand were the "liberals" in the administration. This group included Chester Bowles, Averell Harriman, and James C. Thomson Jr. The dominant faction, which maintained 
the hard Iine against Peking, consisted of Dean Rusk, Walter Rostow. and MCGeorge Bundy. Roger Hilsman, then Assistant Secretary of State for Intelligence and Research, fell somewhere in between the two groups, agreeing with each on respective issues. Kennedy heard recommendations from each group, but it was obvious he listened and followed the hard line faction's suggestions, especially on the food issue and on containing the Chinese.

\section{To Offer or Not to offer}

A major controversy within the administration in 1961 and 1962 was over the question of offering food grains to the People's Republic which was then experiencing a tremendous food shortage. The situation in china was caused by an expanding population while at the same time agricultural output was declining.'

The first recommendation to Kennedy came from George McGovern, Director of the Food for Peace Program. In May of 1961. MCGovern circulated a memorandum to the state Department and the White House to make the administration more aware of the Chinese food crisis. MCGovern asked Bundy and Rostow to ask Kennedy to publicly affirm the availability of food in the U.S. that could be delivered to China. According to MCGovern, this would "dramatically emphasize the humanitarian side" of the administration and Kennedy himself. 1

${ }^{1}$ MCGovern to Bundy and Rostow, May 24, 1961. Box 22, National Security Files, John F. Kennedy Library Archives, Dorchester, Massachusetts. 
This recommendation went directly to the heart of the issue. As MGGovern put it, "the stark, fact is that millions of human beings are in misery while our storage facilities are filled with food we don't need." 2 This was something the hard Iine faction nor Kennedy could deny and MeGovern was willing to illustrate the situation in cold, hard terms. In November of 1961, MCGovern again sent a memorandum to the White House, asking for some action, claiming that "we are being besieged with letters favoring the shipment of grain to Red China." ${ }^{3}$ Both memoranda underlined the seriousness of the crisis.

An example of the letters received was one from the American Friends Committee on National Legislation. In December, this organization wrote the State Department, calling for the U.S. to "make a good faith offer quietly and without propaganda fanfare and leave the next move up to the Chinese Communists." 4 Letters such as this came predominately from church organizations and citizens who generally maintained to offer food was the just thing to do.

The State Department joined the controversy in January of 1962 as Hilsman presented a report from the Department of

$$
2 \text { Ibid. }
$$

${ }^{3}$ MCGovern to Rostow, November 28, 1961: Box 22, National Security Files.

${ }^{4}$ American Friends Committee on National Legislation to State Department, December 20, 1961. Box 15, Personal Papers of James C. Thomson Jr., John F. Kennedy Library Archives, Dorchester, Massachusetts. 
Intelligence and Research. Overall, the report recommended against offering food, but it also raised several strong reasons for offering food. The first of these points was that a U.S. Offer would motivate the Chinese to question their own belligerent attitude towards the administration. A second motive for making the offer was that it would not isolate Peking after the Sino-Soviet split. Lastly, an offer of food would serve as a means to prevent the Chinese from contemplating a desperate push into southeast Asia in search of food. 5 However, the report continued to assess the situation by listing the negative aspects. It estimated that the U.S. could not hope to attain a chinese agreement on nuclear weapons in return for the grain, nor would the Chinese refrain from their militant stance in Asia. 6 Hilsman believed that these negative aspects outweighed any good that could come from the food offer and thus recommended against it.

Hilsman's report failed to reveal the true implications of this offer. The report asked too much from Peking, and once it estimated that returns would not be forthcoming. Hilsman recommended against the offer. What Hilsman did not foresee was the initial gains this offer could procure in opening up the relationship.

Ten days after the Hilsman report, Chester Bowles countered

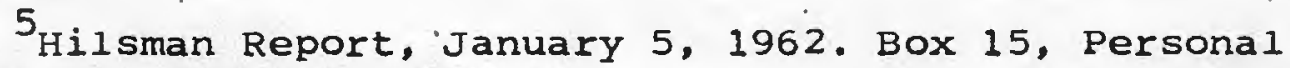
Papers of James C. Thomson Jr.

${ }^{6}$ Ibid. 
with the first of many memoranda to the President on this issue. Bowles made the point that China's situation was not a temporary one, claiming that estimates saw the food deficits continuing for the next decade. Summarizing, this report emphasized that "it seems clear that China will be increasingly forced to look to foreign growers for the necessary food." 7 He believed China could do this in two ways: expansion of trade or military expansion into southeast Asia. In contrast to Hilsman's report, Bowles was optimistic over how an offer to the Chinese might encourage better relations between peking and washington. This memorandum correctly asserted that the U.S. should be willing to take the initiative on this issue. The last recommendation Bowles made once again countered Hilsman because Bowles concluded that an offer of food might give the U.S. leverage over China, especially if the Sino-Soviet split was as serious as thought. 8

This report was more realistic and optimistic than Hilsman's. Bowles realized that the U.S. could not expect too much too soon. He knew that while an offer might not solve all problems, the administration had nothing to 10 se.

A second Bowles report went to Kennedy in February. In this memorandum, Bowles again played on the anxieties of Kennedy, stressing that the Chinese could use military expansion

7 Bowles to Kennedy, January 15, 1962. Box 113A, President's Office Files, John F. Kennedy Library Archives, Dorchester, Massachusetts.

${ }^{8}$ Ibid. 
to attain food if the situation remained desperate. ${ }^{9}$ The theme of this recommendation was that the President could block this need to expand by offering food. This would protect U.S. interests in Southeast Asia and give Kennedy one less worry. In a way, a food offer would help "contain" the Chinese.

Other members of the "liberal" faction were also beginning to pass along their recommendations. Averell Harriman, then Assistant Secretary of State for Far East Affairs, sent a memorandum to his superior, Rusk, in April of 1962. Harriman strongly favored offering food to Peking, basing most of his assumptions on the Bowle's information. Harriman made the point that the U.S. gave the Chinese ammunition to continue their belligerence every time the U.S. failed to act. ${ }^{10}$ In other words, Harriman was advocating that the U.S. take the initiative here. The U.S. had the food, remaining the apprehensive party in the relationship.

A third member of this faction who believed in taking the initiative was Bowles' assistant, Jame C. Thomson Jr. Thomson proposed that the U.S. should initiate discussion at the Warsaw Talks, a series of informal meetings between the People's Republic and the U.S. ${ }^{11}$ Again, this would show the

9 Bowles to Kennedy, February 6, 1962. Box 113A, President'd Office Files.

10 Harriman to Rusk, April 13, 1962. Declassified April 25, 1979. (Washington, D.C.: Carrollton Press, Inc.), Abstract 396-C

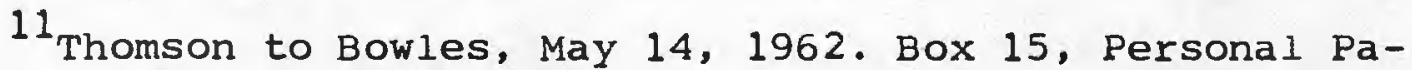
pers of James C. Thomson Jr. 
Chinese that the U.S. was interested in bettering relations.

In May of 1962, Hilsman offered another report, but this time with a change in tone. He was now leaning towards recommending the offer, but was unsure how. Hilsman could not decided if a pubiic or private offer was best. The important issue here is that Hilsman could now see the positive merits of an offer and how "it might well make it possible for other forces to bring about changes." 12

Before looking to the other faction, a discussion on Kennedy's perception of the problem is vital. The President was aware of the food shortage in Red China, with Bowles providing additional information. In January of 1961, at his first news conference, Kennedy made his initial statement on the issue, maintaining the U.S. would not use food as "propaganda efforts" against the Chinese. 13 As time went on, Kennedy remained skeptical, unwilling to make the first move or take the initiative on this or any other related issue. Kennedy believed the chinese had to act first.

This was not Kennedy's first involvement with such a situation. In 1957, the question arose over sending food to Poland, a communist nation. As a member of the senate at the time, Kennedy spoke out in favor of sending food. Kennedy maintained that "a considerable body of opinion would look

12 Hilsman Report, Declassified November 7, 1979.(Washington, D.C.: Carroliton Press, Inc., 1980), Abstract 767-e.

${ }^{13}$ China and U.S., 1955-1963. Kwan Ha Yim, gen. ed., (New York:Facts on File, Inc., 1973), p. 145. 
with favor upon an administration decision approving economic assistance to the people of Poland."14 The senator continued by emphasizing that the U.S. would at least demonstrate that it was willing to help "hungry and impoverished people."15 Five years later kennedy would hear the same argument from MCGovern, yet failed in the end to offer food to the hungry and impoverished people of mainland China.

On May 23, 1962, Kennedy told the press that it was up . to Peking to ask for food, implying that he would not take the initiative. His statement concluded with, "I have said from the beginning, we would certainly have to have some idea as to whether food was needed...up to the point, we have received no such indication."16 kennedy, who had always maintained that the administration should keep the door open to the Chinese, refused to budge on this issue or any other. Rusk agreed with Kennedy on this issue. The secretary of State believed the U.S. could not offer food without the a request from Peking, since it would appear as though the administration was rewarding the chinese for being hostile. In June, 1962, at a meeting with Prime Minister Macmillan of the United Kingdom, Rusk maintained that if the United States

14 William F. Knowland and John F. Kennedy, "Should U.S. Give Aid to Communist Countries" Foreign Policy Bulletin 36 (April 15, 1957): 117 .

${ }^{15}$ Ibid.

${ }^{16}$ China and U.S. Far East Policy, 1945-1967. (Washington, D.C.: Congressional Quarterly Service, 1967), p. 112. 
offered food, then the U.S. would be playing into the hands of Peking. 17 This gave Rusk the appearance of being a hard Iine advocate in regard to china. Others, such as Rostow and Bundy, agreed with such assessments, recommending to Kennedy that he wait and see if Peking came to the U.S. first.

\section{Implications}

The Kennedy administration never made an offer to China. The chance to initiate better relations with Peking passed by untaken due to kennedy's adherance to the hard Iine. The door which he often spoke of remained closed, keeping relations chilled.

1962 closed with Kennedy pondering the future consequences of a hostile China in possession of nuclear capability. If Kennedy's fear was real, he should have seen the need to act when he had the chance. If Kennedy truly sought better relations with Peking, then he had missed a golden opportunity to take the initiative. If he had made an offer, it would have been a positive step towards a new China policy.

17 State Department Memorandum, June 24, 1962. Box 15 , Personal Papers of James C. Thomson, Jr. 


\section{CHAPTER VI}

\section{DISARMAMENT AND CHINA}

When John Kennedy was seeking the presidency, he spoke often about the need to make the world safer, citing the fact that nuclear weapons had increased tremendously in his political lifetime. Although Kennedy ran on the theme of filling the fictional "missile gap", he was sincere in his hopes for beginning arms negotiations as President.

In the early $1960^{\circ} \mathrm{s}$, England, the Soviet Union, and the United States possessed all the nuclear weapons in existence. In several years the Chinese and the French were expected to detonate their first nuclear devices. When this occurred, it would create the need to incorporate them into nuclear disarmament negotiations. The Kennedy administration did try to bring in the French, but not the chinese. Again, the President was short-sighted in his China policy.

\section{Kennedy Hopes}

When it came to the disarmament issue, the chinese communists were always on Kennedy's mind, but the issue never went beyond thought and into any form of action. In the summer of 1960, he expressed in a campaign speech the need to have a "flexible readiness for revision of the U.S. China policy" and suggested that the Chinese be included in a test 
ban treaty. ${ }^{1}$ In September, he made the same assertion, but spoke of the need for the Soviets to discuss disarmament with Peking in order to illustrate to the Chinese that a "reduction in the pace of the arms race and a diminuation of threat of war can be achieved." 2 This statement, calling for the soviets to deal with the Chinese, eventually became the Kennedy policy on disarmament.

While Kennedy spoke of the need to seek arms control, future members of his administration were expressing criticism of the Eisenhower policy on disarmament. These critics believed that the Republican administration took no steps to include the Chinese in the disarmament process. Overa11, the policy was seen as a "frozen, negative, and sterile" stance towards the chinese. ${ }^{3}$ After the election, these critics had their chance to improve on this policy, but failed to go beyond it.

\section{The Test Ban and China}

Chapter Three dealt with the issue of the Sino-Soviet split, an event that directly influenced disarmament. Kennedy was well aware of the implications of the dispute from

${ }^{1}$ Kenneth $T$. Young, Negotiating with the Chinese Communists (New York: MoGraw-Hill, 1968), p. 229.

2 "Disarmament and Arms Control", September, 1960. Box 993, Pre-Presidential Papers of John F. Kennedy, John F. Kennedy Library Archives, Dorchester, Massachusetts.

${ }^{3}$ James C. Thomson Jr, to Ben jamin Reed, September 1 , 1960. Box 993, Pre-Presidential Papers of John F. Kennedy. 
various reports, analysis, and recommendations he had received. The causes and effects were clinically broken down. and U.S. policy reflected these findings. In each of these reports there appeared a section on disarmament, something Kennedy either chose to read quickly or not at all.

The CIA report of April, 1961 explored the relationship between the dispute and the path to disarmament. In this report, the CIA concluded that Peking was wary of Khrushchev's policy of seeking detente with the U.S. The Chinese policy ran counter to this, for China was seen by the CIA as unwilling to join arms talks until it had obtained nuclear capability. ${ }^{4}$. If the U.S. cooperated with the soviets and agreed to negotiate, both Washington and Moscow would have to keep an isolated Peking in mind.

It is interesting to note that a letter from Chiang Kai-shek was received by Kennedy on the same day as the CIA report. Its contents ran counter to the CIA report, stating that the Peking regime would go along with Moscow on any disarmament agreement and that Kennedy did not have to deal directly with the mainland on this issue. ${ }^{5}$ obviously the Generalissimo was out to protect his own position by discrediting the significance of Peking's.

${ }^{4}$ CIA Report, April 1, 1961. Box 21, National Security Files, John F. Kennedy Library Archives, Dorchester, Massachusetts.

${ }^{5}$ Chiang to Kennedy, April 1, 1961. Box 113A, President's Office Files, John F. Kennedy Library Archives, Dorchester, Massachusetts. 
Unfortunately, Kennedy accepted some of Chiang's hypothesis. He was well aware of the significance of the SinoSoviet dispute and realized Peking was moving further away from Moscow's influence, especially on the issue of disarmament. However, the administration refused to interpret this as a sign to take the initiative. There existed the need to at least attempt to induce the Chinese to negotiate. It may have been fruitless, but there was nothing to lose and all to gain. Instead of trying this, Kennedy chose instead to rely on Moscow to influence Peking, something Chiang, as well as Kennedy, believed would suffice. A memorandum on the China policy, written just after the 1960 election, illustrated this idea, asserting that the Russians could and would restrain the Chinese on nuclear weapons and convince Peking to negotiate. ${ }^{6}$

Kennedy once again illustrated his unwillingness to take the initiative. America had to act if it wanted to stop the deterioration of American-sino relations. Peking could afford to wait and then negotiate after developing nuclear capability, giving them a bargaining chip against the United States. The ball was clearly in Kennedy's court.

Perhaps Kennedy did not give the Chinese the respect they deserved. In 1963, at a state Dinner, the President remarked that he was worried about the future problems the Chinese presented, citing the threat the Chinese posed once

${ }^{6}$ State Department Memorandum, November, 1960. Box 14, Personal Papers of James C. Thomson Jr., John F. Kennedy Library Archives, Dorchester, Massachusetts. 
they obtained nuclear weapons. For a fleeting moment the President of the United States sounded very much like a racist when he concluded his statement with "in the case of the Chinese, it really doesn't matter, because the Chinese are perfectly prepared for nuclear war; because of their lower value of life, they are prepared to lose hundreds of millions if necessary." 7

Following the Cuban missile crisis, Kennedy began to accelerate his plans for arms negotiations. The treaty; eventually signed by the Soviets and the Americans on July 25, 1963, was an agreement banning all nuclear tests except underground explosions. This agreement should not be denigrated as a limited and useless treaty. In reality, it was a first step between the super-powers. Both Kennedy and Khrushchev faced domestic criticism because of this treaty, but both should be applauded for taking this step, especially in light of this criticism. On the other hand, both should be criticized for looking to the other to solve the China issue. Kennedy hoped Khrushchev could assist him and make Peking see the need to negotiate. W. Averell Harriman, head of the U.S. delegation to the Vienna talks, was instructed by Kennedy on the methods of hopefully attaining Khrushchev's cooperation. The President reminded Harriman to keep China in mind while in Vienna and to stress the importance of this issue

7 Oral History Interview, William R. Tyler, oral History Colletion, John F. Kennedy Library Archives, Dorchester, Massachusetts. 
to Khrushchev. Specifically, Kennedy believed Khrushchev had to "force China or try to force China to agree to a $1 \mathrm{im-}$ ited test ban." 8 Llwellyn Thompson, one time ambassador to the Soviet Union, believed Khrushchev agreed with Kennedy on the importance of China and disarmament, but also believed that the Sino-Soviet split had diminished any influence he had over Peking. In fact, Thompson maintained that Khrushchev was so disgusted with Peking that he did not care what China did. ${ }^{9}$ Thompson's view was consistent with the CIA report and illustrates how important it was for an American initiative. If the Soviets could not force China to sign an agreement, Kennedy instructed Harriman to propose another method of possible control to Khrushchev. This prposal was to have the Soviets and the Americans attempt to hinder the chinese developmental program. Kennedy instructed Harriman to ask the Soviet leader if this was possible. In effect, Kennedy wanted to know if there was some way the chinese program could be sabotaged. 10

After the treaty was signed by the two delegations, Khrushchev and Harriman had the opportunity privately to discuss China. Acting on Kennedy's instructions, Harriman asked the Soviet Premier if he could "deliver China."11 Harriman

${ }^{8}$ Oral History Interview, Llwellyn E. Thompson, Oral History Collection, John F. Kennedy Library Archives.

${ }^{9}$ Ibid.

10 Ibid.

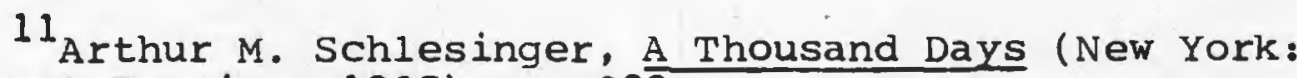
Fawcett Premier, 1965), p. $82 \overline{9}$. 
told Khrushchev that the U.S. intended to try and get France to sign the treaty. The Soviet leader simply told Harriman that China was "your problem."12.

\section{The Horizon}

The test ban treaty was 1 imited in several ways. It banned nuclear tests, except underground explosions, and failed to take into consideration potential nuclear nations. Kennedy and Khrushchev cannot be condemned for this, but they should be criticized for a lack of willingness to face up to the problem, especially in regards to the china question.

Kennedy constantly spoke of the threat posed by Peking, but was too cautoius to try and alleviate the danger. He expected the Soviets to do his dirty work and, when Khrushchev refused, the work went undone. John Kennedy cannot be condemned for not obtaining the chinese signatures on the treaty, but for not trying to obtain them.

12 Ibid. 
CHAPTER VII

CONCLUSIONS

In the twenty years since his death, John F. Kennedy has been elevated to near sainthood by some biographers, friends, and the general public. Most people think that John Kennedy was an outstanding leader and President. This study is not concerned, however, with the personality of John Kennedy. This image of Kennedy is mentioned because his fictional aura affects public conception of his policies. Twenty years have passed, allowing scholars to study Kennedy in an objective light, void of emotion and personal regard. This study has tried to reach that level of objectivity.

Supporters of Kennedy claim that if he had lived, his second term would have clearly illustrated the soundness of his policies. Statements such as these have made John Kennedy the "what if" President of the twentieth century. Some scholars prefer to paint a glorified picture of how the second term would have been more successful. This is fine if one is trying to write a best seller, but it does not fit the purpose of a scholarly investigation. The purpose of this study was not to forecast what might have been, but to look at kennedy's record and analyze what did happen.

What this record does show is that Kennedy was unwilling to discard the existing policy left to him by the previous 
administration. The Eisenhower policy, in general, worked to maintain the credibility of the Chinese. Nationalists while refusing to acknowledge the Chinese Communists. In 1960, many believed Kennedy would move away from this policy. These people believed this not because of evidence, but because of appearance. The theme of the New Frontier was a deceiving one. It gave the impression that kennedy was going to be a president of action and purpose, which was true. However, the New Frontier also meant Kennedy was going to be an active leader against communism, leading to more stringent policies against the Chinese Communists. The difference in ages also led the people to see Kennedy as dynamic and willing to look beyond the existing policy. These conceptions of Kennedy would have been different if people only took the time to look at his record.

Kennedy matured in the immediate post-war years. Serving as both a Congressman and Senator, Kennedy was exposed to numerous individuals and political movements. The most unique individual and movement was Joseph McCarthy and MCCarthyism. Kennedy and McCarthy shared an interesting relationship for several years. Kennedy's brother Robert worked on McCarthy's subcommittee and the Wisconsin Senator vacationed several times at the Kennedy estate on Cape Cod. The two men grew apart as McCarthy's investigations spread and eventually the friendship ended. The legacy of McCarthyism stayed with Kennedy long after the friendship had ended, even as he entered the White House in 1961. 
China had been a focal point of the McCarthy investigations and Kennedy, as President, remembered the scars they had left on members of the Truman administration. In 1960, emotions within the United States were mixed on China and Kennedy did not want to create any controversy. This partially led him to remain rigid and adhere to the Eisenhower policy.

This rigid stance has been thoroughly documented in this study, especially in the chapters dealing with the United Nations, containment, and disarmament. The U.N. policy was essentially the same as Eisenhower's, maintaining Taiwan, while working to postpone a vote on the admission of Peking. Containment remained a strong element of the china policy. Political, economic, and military assistance to Asian nations contributed to Kennedy's policy of surrounding the chinese mainland with pro-American governments. Finally, in the area of disarmament, Kennedy acted as Eisenhower, unwilling to deal directly with the chinese or take the initiative on this sub ject.

The Eisenhower policy was maintained in response to real or imagined opposition. Kennedy feared his administration was being closely scrutinized by several movements in regards to the China issue. The first movement was the China Lobby. In all fairness to Kennedy, this was a formidable barrier to a new policy, but the degree of trouble it could have caused is debatable. The point is that the longer Kennedy allowed this movement to influence him on this issue, the harder it was going to be to change the policy in the future. 
The second movement that confronted Kennedy was Congress. In general, the Congress was conservative on the China issue and looked to maintain the status quo. Again, this was a force that Kennedy had to deal with if he wanted to change the American policy.

The last movement that Kennedy feared was public opinion. However, in comparison to the China Lobby and Congress, Kennedy clearly over-estimated the sentiment of the American electorate. Surveys discussed in earlier chapters have illustrated this point. Kennedy constantly maintained that he needed to mobilize public support for his policy, yet he already had it. In the end, he actually mobilized support against China. A series of surveys done by the American Institute of Public opinion demonstrated that Kennedy, by constantly criticizing Peking as the major threat to world peace, convinced the electorate of this. In 1961, only 32 percent believed this, but by 1964,56 percent had the impression that China posed the greatest threat to the United States. ${ }^{1}$ In essence, Kennedy mobilized support for the existing policy, allowing him to maintain it.

With Kennedy's death came the end of his administration but not the end of the China policy. During his tenure Kennedy missed the chance to create better relations with the Chinese Communists. Although it is safe to say the relationship

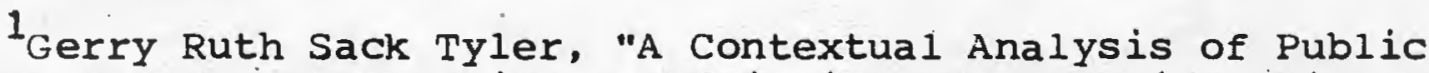
opinion Polls: The Question of Admission of Communist china to the United Nations" Ph.D. dissertation, Yale University, 1972, p. 131 . 
would not have completely thawed, but progress could have been made towards more conciliatory relations. Specifically, Peking would not have been isolated from the U.S. and there was the potential for nuclear negotiations. Also, by keeping the door open to a better relationship, Kennedy would have kept the Chinese more involved in international issues. However, by adhering to the old policy, he tended to isolate the Chinese at the expense of seeking better international cooperation. 
The primary sources proved to be the vital area of the investigation and an introduction to them is necessary in order to acquaint the reader with their nature.

The Oral History Collection at the Kennedy Library was used as a means of trying to come to terms with the administration's policy as a whole. I was able to read numerous interviews and this allowed me to come to some sort of a coriclusion. It is important to remember that each interview was not taken as gospel truth, but instead I tried to use the interviews as a guide to the administration's policy.

Kennedy's Pre-Presidential Papers were used to see how and if his thoughts on China had changed over the lenyth of his tenure in office. The Stevenson Report of 1960 and various speeches were the best documents in these files.

The National Security Files provided an insight on the National security Council and the administration's policy, especially on the crisis in Laos. Memorandum from McGeorye Bundy was also prevalent in these files and gave ar indication of Kennedy's personal views. This was the case also with the President's Office Files.

The Personal Papers of Hilsman and. Thomson presented a wide range of documents. Each man also included ihisi own analysis of policy that I used in order to compare to public statements. In general, I used all these documents so that I did not have to rely on a secondary source for analysis. By personally studying these documents, I was able to come to my own conclusions. 


\section{Primary}

\section{Unpublished}

Declassified Document, CIA Report, January 19, 1961. Washington, D.C.: Carrollton Press, Inc., 1980.

Declassified Document, lidepartment of State Memorandum, May 24, 1961. Washington, D.C.: Carrollton Press, Inc., 1976.

Declassified Document, Department of State Memorandum, July

31, 1961. Washington, D.C.: Carrollton Press, Inc., 1976.

Declassified Document, Department of State Memorandum, April

13, 1962. Washington, D.C.: Carrollton Press, Inc., 1980.

Declassified Document, Department of State Memorandum, May 26, 1962. Washington, D.C.: Carrollton Press, Inc., 1980.

oral History Collection, John F. Kennedy Library Archives, Dorchester, Massachusetts. Interviews of:

-George Kennan

-Henry R. Luce

John Cabot Moors

-Llwellyn E. Thompson

-William R. Tyler

Declassified Documents, John F. Kennedy Library Archives, Dorchester, Massachusetts:

-National Security Files, Boxes 21, 22, 111, 195, 313, $314,328,336$.

-Pre-Presidential Papers of John F. Kennedy, Boxes 993, $1030,1074$.

-President's Office Files, Boxes 28, 33, 62, 113A, 114, 121.

-Personal Papers of Roger Hilsman, Box 1.

-Personal Papers of James C. Thomson Jr., Boxes 5, 6, 7, $14,15$.

\section{Published}

Pentagon Papers, Gravel Edition, Volume II. Boston: Beacon Press.

Papers of Adlai E. Stevenson, Volume VII. edited by walter Johnson. Boston: Little, Brown, and Company, 1977.

Public Papers of the Presidents of the United States. Washington, D.C.: United States Government Printing office, 1962. John F. Kennedy, 1961. 
Public Papers of the Presidents of the United States. Wash-" ington, D.C.: United States Government Printing office, 1963. John F. Kennedy, 1962.

Public Papers of the Presidents of the United States. Washington, D.C.: United States Government Printing office, 1964. John F. Kennedy, 1963.

\section{Secondary}

\section{Unpublished}

Tyler, Gerry Ruth Sack. "A Contextual Analysis of Public Opinion Polls: The Question of Admission of Communist China to the United Nations." Ph.D. dissertation, Yale University, 1972.

\section{Published}

Ambrose, Stephen E. Rise to Globalism: American Foreign Policy Since 1938. London: The Penguin Press, 1971.

Appleton, Sheldon. "The United Nations 'China Tangle'." Pacific Affairs 35 (Summer, 1962): 160-167.

Bowles, Chester. Promises to Keep. New York: Harper and Row, 1971 .

- "The China Policy Reconsidered:" Foreign Affairs 38 (April, 1960): 332-353.

Boyle, William and Akra, Neyland. "The United States and the Admission of Communist China." Political Science Quarterly 76 (September, 1961): 332-353.

China and U.S. Far East Policy, 1945-1967. Washington, D.C.: Congressional Quarterly Service, 1967.

Clubb, Oliver E. Jr. The United States and the Sino-Soviet Bloc in Southeast Asia. Washington, D.C.: The Brookings Institute, 1962 .

Cohen, Warren. Dean Rusk. Totowa, New Jersey: Cooper Square Publishers, 1980 .

Davis, Forrest and Hunter, Robert A. The Red China Lobby. New York: Fleet Publiṣhing Corporation, 1963.

Dean, Arthur, H. Test Ban and Disarmament: 'The Path of Negotiation. New York: Harper and Row, 1966. 
Donald, Aida, ed. John F. Kennedy and the New Frontier. New York: Hill and Wang, 1966.

Dulles, Foster Rhea. American Policy Toward Communist China. New York: Thomas Y. Crowell, 1972.

FitzSimons, Frances. The Kennedy Doctrine. New York: Random House, 1972.

Friedman, Edward and Seldon, Mark, eds. America's Asia: Dissenting Essays on Asian-American Relations. New York: Patheon Books, 1969.

Gaddis, John Lewis. Strategies of Containment. New York: Oxford University Press, 1982.

Halberstam, David. The Best and the Brightest. New York: Random House, 1969.

Hilsman, Roger. To Move a Nation. Garden City, New York: Doubleday and Company, Inc., 1967.

Hsin-hai, Chang. America and China: A New Approach to Asia. New York: Simon and Schuster, 1965.

Juviler, Peter H. and Morton, Henry W., eds. Soviet Policy Making. New York: Praeger Publishers, 1967.

Kennedy, John F. "A Democrat Looks at Foreign Policy." Foreign Affairs 30 (October, 1957): 44-59. and Knowland, William F. "Should U.S. Give Aid to Communist Countries." Foreign Policy Bulletin 36 (April 15, 1957): 117-119.

Lord, Donald. John F. Kennedy: The Politics of Confrontation and Conciliation. Woodbury, New York: Barron's, 1977.

Low, Alfred D. The Sino-Soviet Dispute. Rutherford; New Jersey: Fairleigh Dickinson University Press, 1976.

Paterson, Thomas G. "Bearing the Burden: A Critical Look at JFK's Foreign Policy." The Virginia Quarterly Review 54 (Spring, 1978): 193-212.

Rowland, John. A History of Sino-Indian Relations. Princeton, New Jersey: D. Van Nostrand Company, Inc., 1967.

Rusk, Dean. "The President." Foreign Affairs 38 (April, 1960): 353-369.

Schlesinger, Arthur M. A Thousand Days. New York: Fawcett Premier, 1965. 
Schurmann, Franz and Schell, Orville, eds. The China Reader: Communist China. "New York: Random House, 1967.

Snow, Edgar. "A Report From Red China." Look 25 (January 31, 1961): 85-99.

Sorenson, Theodore. Kennedy. New York: Harper and Row, 1965.

Stebbins, Richard. The United States in World Affairs, 1961. New York: Harper and Row, 1962.

Steele, A.T. The American People and China. New York: McGrawHill, 1966 .

Thomson, James C. Jr. "On the Making of the U.S. China Policy, 1961-1969: A Study in Bureaucratic Politics." China Quarterly 50 (Spring, 1972): 220-243.

; Stahley, Peter; and Perry, John C. Sentimental Imperialists: The American Experience in East Asia. New York: Harper and Row, 1981.

Toye, Hugh. Laos: Buffer State or Battleground. New York: Oxford University Press, 1968.

Weng, Byron S. "Communist China's Changing Attitude Toward the United Nations." International Organization 20 (Fall, 1966): 677-704.

White Theodore, $\mathrm{H}$. The Making of the President, 1960. New York: Atheneum House, Inc., 1961.

Yim, Kwan Ha, ed. China and the U.S., 1955-1963. New York: Facts on File, Inc., 1973.

Young, Kenneth T. Negotiating with the Chinese Communists. New York: McGraw-Hill, 1968. 